\title{
Aerobic Degradation of Petroleum Components by Microbial Consortia
}

Olajire $\mathrm{AA}^{1 *}$ and Essien $\mathrm{JP}^{2}$

${ }^{1}$ Industrial and Environmental chemistry unit, Department of pure and applied chemistry, Ladoke Akintola University of Technology, Ogbomoso, Nigeria ${ }^{2}$ Department of microbiology, University of Uyo, Uyo, Nigeria

\begin{abstract}
This article is a state-of-the-art review on the aerobic degradation of petroleum components that are commonly found in the environment. Numerous microorganisms have been isolated and their phylogeny and metabolic capacity to degrade a variety of aliphatic and aromatic hydrocarbons have been demonstrated. This review focuses on recent progress on how microbes degrade hydrocarbons and heteroaromatic components of petroleum contaminants directed towards better understanding of the aerobic degradation processes and their exploitation for bioremediation. The phylogenetic diversity of the oil-degrading microbes was also discussed.
\end{abstract}

Keywords: Petroleum components; Aerobic degradation; Microorganisms; Phylogenetic diversity; Environment

\section{Introduction}

The biodegradation of petroleum and other hydrocarbons in the environment is a complex process, whose quantitative and qualitative transformations depend on the nature and amount of the oil or hydrocarbons present, the ambient and seasonal environmental conditions, such as free or dissolved oxygen, optimum temperature for oil degradation $\left(20-35^{\circ} \mathrm{C}\right)$, physical and/or chemical dispersion of oil, turbulent conditions as opposed to quiescent conditions, and the composition of the autochthonous microbial community [1-7]. Microbial degradation of oil has been shown to occur by attack on aliphatic or light aromatic fractions of the oil, with high-molecularweight aromatics, resins, and asphaltenes considered to be recalcitrant or exhibiting only very low rates of biodegradation, although some studies have reported their removal at high rates under optimal conditions $[8,9]$.

Biodegradation rates generally increase with increasing temperature such that ecosystems exposed to extremely low temperatures degrade hydrocarbons very slowly. The microbial degradation of petroleum in aquatic environments is limited primarily by nutrients such as nitrogen and phosphorus; salinity and pressure may be important in estuarine and deep-sea regions, respectively. Oxygen, nutrient concentrations, moisture, and $\mathrm{pH}$ are predominant factors in determining biodegradation rates in soil.

Petroleum is a complex mixture of different hydrocarbons including aliphatic (linear or branched), cycloalkanes, mono- and polyaromatics, asphaltenes and resins and majority of these compounds are stable, toxic, and carcinogenic [10,11]. Petroleum compounds such as alkanes, benzene, toluene, ethyl benzene, and xylenes (BTEX) and some polycyclic aromatic hydrocarbons (PAHs) are biodegradable under the proper environmental conditions $[3,12]$ and low salinity marine habitats [13-16]. However, higher molecular PAHs, polycyclic aromatic sulphur heterocyclics (PASHs), methyl tertiary butyl ether (MTBE), gasoline additive and other components of petroleum products may be recalcitrant to biodegradation. The non-biodegradable components can still pose a high risk in the immediate vicinity of the area in which they remain. Petroleum hydrocarbons are therefore major contaminants in the environment and they cause damages to the surrounding ecosystems. Oil-contaminated soil, groundwater, and/ or wastewater may contain a mixture of contaminant types including salts, organics, alcohols, phenols, acid, radionuclides, PAHs, and trace elements like zinc, cadmium, mercury, copper, chromium, lead etc. at widely varying concentrations [17-19]. The present review was focus on aerobic degradation process of various components of petroleum by microbial consortia. The main petroleum components discussed include aliphatics, alicyclic, and aromatics hydrocarbons as well as the $\mathrm{N}$-, S-and O- heterocyclic aromatic hydrocarbons. Also addressed is the phylogenetic diversity of the oil-degrading microbes.

\section{Biodegradation of Petroleum Compounds}

Crude oil is a mixture of hydrocarbons composed of mainly heteroatomic and non-heteroatomic hydrocarbons [11]. To date many studies have reported the ability of microorganisms to utilize crude oil components as the growth substrates (Table 1). Zvyagintseva et al. [20] have reported degradation of isoprenoid and n-alkane fractions of crude oils to a significant extent by an enrichment developed from the brines of the Kalamkass oil fields in Kazakhstan. Diaz et al. [21] have enriched microbial consortia, MPD-7 and MPD-M from Cormorant oil fields in North Sea and sediments associated with mangrove roots, respectively. These cultures degraded aliphatic and aromatic hydrocarbons in crude oil. Total oil degradation by MPD-7 ranged from 20 to $38 \%$, while MPD-M degraded much higher amount of crude oil ranging between 45 and $48 \%$. In a subsequent study, Diaz et al. [22] have immobilized the MPD-M culture on polypropylene fibers and the culture was reported to degrade crude oil. Riis et al. [23] showed the degradation of diesel fuel by microbial communities extracted from Argentinean saline soils. In addition, these authors isolated several halotolerant bacteria of the genera Cellulomonas, Bacillus, Dietzia, and Halomonas with the ability to degrade crude oil as the carbon source. Obuekwe et al. [24] reported the isolation of Fusarium lateritium, Drechslera sp, and Papulaspora sp. from a salt marsh in the Kuwaiti desert that are capable of degrading crude oil as the sole carbon source. Similarly, several

${ }^{*}$ Corresponding author: Olajire AA, Industrial and Environmental chemistry unit, Department of pure and applied chemistry, Ladoke Akintola University of Technology, Ogbomoso, Nigeria, Tel: 2348033824264; E-mail: olajireaa@yahoo.com

Received June 29, 2014; Accepted September 11, 2014; Published September 30, 2014

Citation: Olajire AA, Essien JP (2014) Aerobic Degradation of Petroleum Components by Microbial Consortia. J Pet Environ Biotechnol 5: 195. doi:10.4172/2157-7463.1000195

Copyright: $\odot 2014$ Olajire AA, et al. This is an open-access article distributed under the terms of the Creative Commons Attribution License, which permits unrestricted use, distribution, and reproduction in any medium, provided the original author and source are credited. 
Citation: Olajire AA, Essien JP (2014) Aerobic Degradation of Petroleum Components by Microbial Consortia. J Pet Environ Biotechnol 5: 195 doi:10.4172/2157-7463.1000195

Page 2 of 22

\begin{tabular}{|c|c|}
\hline Degrader & References \\
\hline Streptomyces albiaxialis & Kuznetsov et al. [28] \\
\hline Enrichment culture, brines of the Kalamkass oil fields, & Zvyagintseva et al. [20] \\
\hline \multicolumn{2}{|l|}{ Kazakhastan } \\
\hline Marinobacter aquaeolei & Huu et al. [27] \\
\hline Bacterial consortia MPD-7 & Diaz et al. [21] \\
\hline Rhodococcus erythropolis , Dietzia maris & Zvyagintseva et al. [29] \\
\hline MPD-M culture immobilized on polypropylene fibers & Diaz et al. [22] \\
\hline Fusarium lateritium, Drechslera sp. & Obuekwe et al. [24] \\
\hline Microbial community, Argentinean soil & Riis et al. [23] \\
\hline Cellulomonas sp. Bacillus sp. Dietzia sp. Halomonas sp. & Riis et al. [23] \\
\hline Rhodococcus sp. Gordonia sp. Dietzia sp. Pseudomonas sp. & Borzenkov et al. [30] \\
\hline Actinopolyspora sp. DPD1 & Al-Mueini et al. [107] \\
\hline Bacillus sp. strain DHT & Kumar et al. [31] \\
\hline Halomonas shengliensis & Wang et al. [25] \\
\hline Strain C5 & Chamkha et al. [33] \\
\hline Halomonas sp. C2SS100, Pseudomonas sp. C450R & Mnif et al. $[26,32]$ \\
\hline Haloferax sp. Halobacterium sp. Halococcus sp. & Al-Mailem et al. [111] \\
\hline Amycolicicoccus subflavus DQS3-9A1 & Wang et al. [34] \\
\hline Marinobacter sedimentalis, Marinobacter falvimaris & Al-Mailem et al. [36] \\
\hline
\end{tabular}

Table 1: Microorganisms having degradation potential for crude oil.

authors have isolated pure cultures including Halomonas shengliensis [25], Halomonas sp. strain C2SS100 [26], Marinobacter aquaeolei [27], Streptomyces albiaxialis [28], Rhodococcus erythropolis, and Dietzia maris [29] from oil fields, production water, and other saline environments that degrade crude oil as the source of carbon. Borzenkov et al. [30] reported the isolation of several strains of hydrocarbon-oxidizing bacteria representing the genera Rhodococcus, Gordonia, Dietzia, and Pseudomonas from oil and stratal waters of Tatarstan, western Siberia, and Vietnam oil fields. All these strains oxidized $n$-alkane fraction of crude oil. A Bacillus sp. strain DHT, isolated from oil contaminated soil, grew and produced biosurfactant when cultured in the presence of variety of hydrocarbons including crude oil, diesel oil, hexadecane, naphthalene, pyrene, dibenzothiophene, salicylate, catechol, and phenanthrene as the sole carbon sources at $30-45^{\circ} \mathrm{C}$. However, no growth occurred on toluene, phenol, 2-hydroxyquinoline and carbazole [31]. Similarly, Mnif et al. [32] have reported the isolation of several strains of thermophilic and mesophilic hydrocarbon degrading as well as biosurfactant producing organisms from Tunisian oil fields. Among these, Pseudomonas sp. strain C450R and Halomonas sp. strain C2SS100 were reported to degrade $93-96 \%$ of the aliphatic fraction of crude oil $\left(\mathrm{C}_{13}-\mathrm{C}_{29}\right)$, while producing biosurfactants. Chamkha et al. [33] have isolated a strain C5 closely related to Geobacillus pallidus from a tyrosol degrading enrichment developed from production water from a hightemperature oil field in Tunisia. The organism degraded crude oil and diesel as the source of carbon. Wang et al. [34] have isolated a moderate halophilic actinomycete, Amycolicicoccus subflavus DQS3-9A1 ${ }^{T}$ from oily sludge at Daqing Oil field, China with the ability to degrade crude oil. Later, Nie et al. [35] studied the genetic capability of the DQS3$9 \mathrm{~A} 1^{T}$ to metabolize a range of short-chain and long-chain $n$-alkanes such as propane and $\mathrm{C}_{10}-\mathrm{C}_{36}$ alkanes in crude oil, respectively, as the sole carbon sources. Recently, Al-Mailem et al. [36] have isolated Marinobacter sedimentalis and Marinobacter falvimaris from soil and pond water collected from hypersaline Sabkhas in Kuwait. Isolation of these organisms was accomplished using agar plates provided with crude oil vapor as the sole source of carbon. These studies also showed that both organisms were capable of fixing atmospheric nitrogen and such potential is beneficial for effective bioremediation of petroleum compounds without the need of providing fertilizer. Biodegradations of crude oil or petroleum usually requires the cooperation of more than one single species. Individual microorganisms can metabolize only a limited range of hydrocarbon substrates, so a consortium composed of many different bacterial species with overall broad enzymatic capacities is required to increase the rate of petroleum biodegradation. Hydrocarbon degradation by microbial communities depends on the composition of the community and its adaptive response to the presence of hydrocarbons. Bacteria and fungi are the key agents of degradation, with bacteria assuming the dominant role in marine ecosystems and fungi becoming more important in freshwater and terrestrial environments. Adapted communities, i.e., those which have been previously exposed to hydrocarbons, exhibit higher biodegradation rates than communities with no history of hydrocarbon contamination. The mechanisms of adaptation which include both selective enrichment and genetic changes result in a net increase in the number of hydrocarbon utilizing organisms and in the pool of hydrocarboncatabolizing genes within the community. Petroleum compounds differ in their susceptibility to microbial attack and generally degrade in the following order of decreasing susceptibility [37]: n-alkanes $>$ branched alkanes $>$ low molecular weight aromatics $>$ cyclic alkanes, $>$ polycyclic aromatic hydrocarbons $>$ polar compounds. Although many of these compounds can be relatively easily degraded under soil and fresh water environments [3,12] and low salinity marine habitats [13-16]. Biodegradation rates have been shown to be highest for the saturates, followed by the light aromatics, with high-molecular-weight PAHs and polar compounds (resins and asphaltenes) exhibiting extremely low rates of degradation or may not be degraded at all [38-40].

\section{Biodegradation of petroleum compounds in different ecosystems}

In many ecosystems there is already an adequate indigenous microbial community capable of extensive oil biodegradation, provided that environmental conditions are favorable for oil-degrading metabolic activity. There are several advantages of depending on indigenous microorganisms rather than adding microorganisms to degrade hydrocarbons. First, natural populations must have developed through many years. These microorganisms are adapted for survival and proliferation in that environment. Secondly, the ability to utilize 
hydrocarbons is distributed among a diverse microbial population. This population occurs in natural ecosystems and either independently or synergistically metabolizes various hydrocarbons. Many times, when the amount of microorganisms is sufficient in the contaminated environment, microbial seeding may not be required. Microorganisms (bacteria and fungi) have different rates at which they utilize and degrade hydrocarbons in the soil or water. This rate is reflected in the multiplication and colony forming units (cfu) for the isolated organisms. The use of microorganisms to degrade petroleum hydrocarbon resulting from oil spillage has been a subject of extensive research since the first publication of bacterial growth on petroleum hydrocarbons [41,42]. Several petroleum hydrocarbon degrading microorganisms have been isolated from both soil and marine sources, which are the two major environments affected by petroleum hydrocarbon pollution $[43,44]$. Microorganisms are equipped with metabolic machinery to use petroleum products as a carbon and energy source. The metabolic pathways that hydrocarbon-degrading heterotrophs use can be either aerobic (i.e. they utilize oxygen as the primary electron acceptor) or anaerobic (i.e. they utilize an alternative electron acceptor such as nitrate or sulfate). Aerobic degradation usually proceeds more rapidly and is considered to be more effective than anaerobic degradation because of the less free energy required for initiation and energy yield per reaction. This review mainly focuses on aerobic degradation of petroleum components in different ecosystems.

Soil ecosystem: Petroleum compounds bind to soil components, and they are difficult to be removed or degraded [45]. Petroleum contamination in soil results in an imbalance in the carbon-nitrogen ratio at the spill site, because crude oil is essentially a mixture of carbon and hydrogen. This causes a nitrogen deficiency in oil soaked soil, thus retarding the growth of bacteria and the utilization of carbon sources. Furthermore, large concentrations of biodegradable organics in the top layer soil deplete oxygen reserves in the soil and slow down the rates of oxygen diffusion into deeper layers. Many indigenous microorganisms in water and soil are capable of degrading petroleum contaminants $[46,47]$. Petroleum hydrocarbons in nature are degraded by diverse groups of microorganisms, which are capable of utilizing hydrocarbons as food [48]. The degradation of complex mixtures of hydrocarbons such as crude oil and metals in soil requires mixedpopulations with overall broad enzymic capacities $[43,49]$. Bacteria are the most active agents in petroleum degradation and they work as primary degraders of spilled oil in environment $[50,51]$. Several bacteria are known to feed exclusively on hydrocarbons [52].

Biodegradation of crude petroleum oil from petroleum contaminated soil from North East India was reported by Das and Mukherjee [53]. Acinetobacter sp. was reported to be capable of utilizing $n$-alkanes of chain length $\mathrm{C}_{10}-\mathrm{C}_{40}$ as a sole source of carbon [54]. Bacterial genera, namely, Gordonia, Brevibacterium, Aeromicrobium, Dietzia, 3Burkholderia, and Mycobacterium isolated from petroleum contaminated soil proved to be the potential organisms for hydrocarbon degradation [47,55-59]. The degradation of PAHs by Sphingomonas was reported by Daugulis and McCracken [56]. Tang et al [8] reported the degradation process of crude oil by one artificial microalgal-bacteria consortium. The consortium which was constructed by one axenic Scenedesmus obliquus named GH2 and four oil component-degrading bacteria with known complementary degradative capabilities, including Sphingomonas GY2B, Burkholderia cepacia GS3C, Pseudomonas GP3A and Pandoraea pnomenusa GP3B were reported to completely eliminate alkanes, alkylcycloalkanes and alkylbenzens in 10 and 7 days, respectively. The consortium also preferentially attacked high molecular weight PAHs such as phenanthrene and methylphenanthrenes, a lot of $\mathrm{C}_{2}, \mathrm{C}_{3}$ naphthalene isomers and some extra lower molecular substances were produced during the PAHs degradation. Chang et al. [9] investigated the extent of biodegradation of non-volatile petroleum hydrocarbons $\left(\mathrm{C}_{16}-\mathrm{C}_{34}\right)$ and the associated microbial activity in predominant aggregate sizes during a pilot-scale biopile experiment conducted at $15^{\circ} \mathrm{C}$, with a clayey soil, from a crude oil-impacted site in northern Canada. At the end of 65 -d biopile experiment, $42 \%$ of the $\mathrm{C}_{16}-\mathrm{C}_{34}$ hydrocarbons were reported to be degraded in the nutrientamended macroaggregates, compared to $13 \%$ in the mesoaggregates. Higher microbial activity in the macroaggregates of the nutrientamended biopile was inferred from a larger increase in extractable protein concentrations, compared to the other aggregates. Fungal genera, namely, Amorphoteca, Neosartorya, Talaromyces, and Graphium and yeast genera, namely, Candida, Yarrowia, and Pichia were isolated from petroleum contaminated soil and proved to be the potential organisms for hydrocarbon degradation [55]. Singh [60] also reported a group of terrestrial fungi, namely, Aspergillus, Cephalosporium, and Pencillium which were also found to be the potential degrader of crude oil hydrocarbons. Adenipekun [61] reported that Pleurotus tuberregium have the ability to increase nutrient contents in soils polluted with $1-40 \%$ engine-oil concentration after six months of incubation and reduction in heavy metals after six months of incubation. Hence, the fungus can be employed in decontaminating environment polluted with engine oil. In a similar study, Adenipekun and Isikhuemhen [62] revealed the ability of white rot fungus, $L$. squarrosulus to improve the nutrient contents of the engine oil contaminated soil and an accumulation of $\mathrm{Fe}, \mathrm{Zn}$ and $\mathrm{Ni}$ to an appreciable extent.

Aquatic ecosystem: In aquatic ecosystems, dispersion and emulsification of oil in slicks appear to be prerequisites for rapid biodegradation. Large masses of mousse, tar balls or high concentrations of oil in quiescent environments tend to persist because of the limited surface areas available for microbial activity. Petroleum fractions containing asphalt components are not degraded quantitatively [63]. Therefore, floating tar globules are encountred in the marine environment in increasing quantities because they are practically oxygenated high molecular weight materials that resist furher microbial degradation. When oil spill occurs, a combination of recovery, disposal and the containment of oil is performed thereafter. The conventional methods to remove oil from aquatic ecosystems include; mechanical clean up, chemical clean up and microbial degradation. Mechanical cleaning of spilled oil and dispersant is nearly impossible in "protected" ecosystems. Microbial degradation is the major mechanism for the elimination of spilled oil and dispersants from aquatic environment [64].

Hamzah et al. [65] reported three bacterial isolates identified as Pseudomonas aeruginosa (UKMP-8T), Rhodococcus sp. M15-2 (UKMP-5T), and Rhodococcus sp. ZH8 (UKMP-7T) isolated from groundwater of a crude oil refinery plant. From these three isolates, they designed four bacterial consortia by mixing the single bacterial cultures in the following ratios: (P. aeruginosa: Rhodococcus sp. M152, 1:1), (P. aeruginosa:Rhodococcus sp. ZH8, 1:1), (Rhodococcus sp. M15-2: Rhodococcus sp. ZH8, 1:1), and (P. aeruginosa: Rhodococcus sp. ZH8:Rhodococcus sp. M15-2, 1:1:1), respectively. These bacterial isolates and consortia were reported to show differing preferences for nitrogen source and when fortified with the preferred nitrogen sources and grown in minimal salt medium, within 7 days, all the three single isolates and the four bacterial consortia biodegraded $97.6-99.9 \%$ of Tapis Massa oil without any significant differences. Malik and Ahmed [66] investigated the degradation of petroleum hydrocarbons by an oilfield isolated bacterial consortium. They reported that the biotic 
removal of alkanes was maximum, $90.96 \%$ for tridecane $\left(\mathrm{C}_{13}\right)$ followed by pentadecane $\left(\mathrm{C}_{15}\right)$ at $77.95 \%$, octadecane $\left(\mathrm{C}_{18}\right)$ at $74.1 \%$, while other alkanes showed 56 to $69 \%$ after 24 days of incubation. Among the aromatics, the micro aromatics (benzene, toluene and xylene) quickly evaporated after the 4th day of incubation, while the efficiency on polyaromatic fractions (anthracene, phenanthrene and pyrene) was 46.17 to $55.3 \%$ after 24 days.

The yeast species, namely, Candida lipolytica, Rhodotorula mucilaginosa, Geotrichum sp, and Trichosporon mucoides isolated from contaminated water were noted to degrade petroleum compounds [67,68]. Hidayat and Tachibana [69] demonstrated that Fusarium sp. F092 have the ability to degrade chrysene and the aliphatic fraction of crude oil contaminating liquid culture with artificial sea water (35\%).

Though algae and protozoa are the important members of the microbial community in both aquatic and terrestrial ecosystems, reports on their involvement in hydrocarbon biodegradation are scanty. Walker et al. [70] isolated an alga, Prototheca zopfi which was capable of utilizing crude oil and a mixed hydrocarbon substrate and exhibited extensive degradation of $n$-alkanes and isoalkanes as well as aromatic hydrocarbons. Cerniglia et al. [71] also observed nine cyanobacteria, five green algae, one red alga, one brown alga, and two diatoms that could oxidize naphthalene. None of the Protozoa had been reported to utilize hydrocarbons.

The role of fungi in biodegradation process of petroleum products has been extensively studied and the most common fungi which have been recorded as a biodegrades belongs to following genera: Alternaria, Aspergillus, Candida, Cephalosporium, Cladosporium, Fusarium, Geotrichum, Gliocladium, Mucor, Paecilomyces, Penicillium, Pleurotus, Polyporus, Rhizopus, Rhodotolura, Saccharomyces, Talaromyces and Torulopsis [72-81].

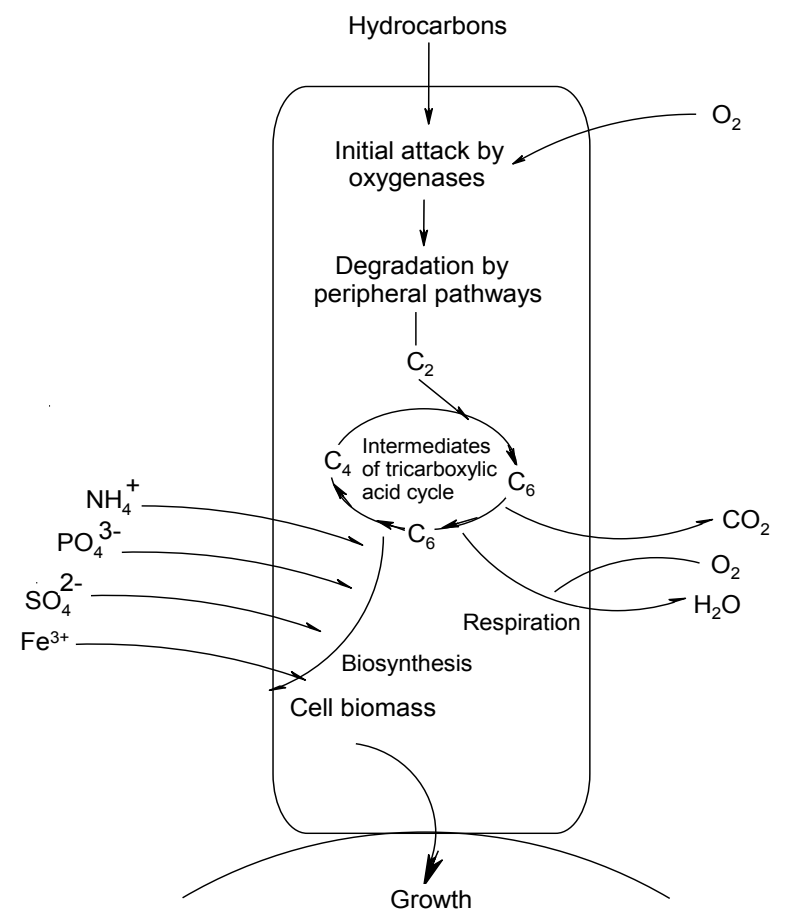

Figure 1: Main principle of aerobic degradation of hydrocarbons by microorganisms.
In the aquatic ecosystems, fungi plays an important role during their ability in removing hazardous compounds from the water, whereas sediment particles contaminated with crude oil from oil spills is one of the desired ecological niche to fungi which inhabits such substrate and use carbon source from hydrocarbons in polluted sediment particles to biodegrade crude oil from the sediments in the beaches. Fungi have been found to be better degraders of petroleum than traditional bioremediation techniques including bacteria, and although hydrocarbon degraders may be expected to be readily isolated from a petroleum oil- associated environment $[80,81]$. The ability of most fungi to produce extracellular enzymes for the assimilation of complex carbohydrates makes possible the degradation of a wide range of pollutants. They also have dvantage of being relatively easy to grow in fermenters, thus being suited for large scale production. Another advantage is the ease of separation of fungal biomass by filtration due to its filamentous structure. They are also less sensitive to variations in nutrients, aeration, $\mathrm{pH}$, temperature and have a lower nucleic content in the biomass as compared to yeasts.

Marine ecosystem: The microbial response to an oil spill at sea is dependent on numerous factors, including the oil composition and degree of weathering, as well as environmental conditions, particularly temperature and nutrient concentrations [16]. Nevertheless, there are some typical patterns; most notable is the large increase in abundance of Alcanivorax spp., which degrade straight-chain and branched alkanes [84-87], followed by Cycloclasticus spp., which degrade PAHs $[15,52,86,87]$.

Since the cultivation of Alcanivorax borkumensis [88], functional genomic, biochemical and physiological analyses have revealed the underlying basis of its success [52,89-91]. While it lacks catabolic versatility, utilising alkanes almost exclusively as carbon and energy sources, it has multiple alkane-catabolism pathways, with key enzymes including alkane hydoxylases (a non-haem diiron monooxygenase; AlkB1 and AlkB2) and three cytochrome P450-dependent alkane monooxygenases [89]. Their relative expression is influenced by the type of alkane supplied as carbon and energy source and phase of growth [89]. Alcanivorax borkumensis also possesses a multitude of other adaptations to access oil (e.g. synthesis of emulsifiers and biofilm formation [89] and to survive in open marine environments [87,89]. Acinetobacter spp., which are commonly isolated from oilcontaminated marine environments [92], also have a diverse array of alkane hydroxylase systems enabling them to metabolize both shortand long-chain alkanes [92,93].

Microbial degradation of petroleum hydrocarbons in a polluted tropical stream in Lagos, Nigeria was reported by [94]. Nine bacterial strains, namely, Pseudomonas fluorescens, P. aeruginosa, Bacillus subtilis, Bacillus sp., Alcaligenes sp., Acinetobacter lwoffi, Flavobacterium $s p$., Micrococcus roseus, and Corynebacterium sp. were isolated from the polluted stream which could be responsible for the degradation of the crude oil.

\section{Aerobic degradation of petroleum compounds}

The most rapid and complete degradation of the majority of organic pollutants is brought about under aerobic conditions. Figure 1 shows the main principle of aerobic degradation of hydrocarbons [95]. The initial intracellular attack of organic pollutants is an oxidative process and the activation as well as incorporation of oxygen which is the enzymatic key reaction catalyzed by oxygenases and peroxidases. Peripheral degradation pathways convert organic pollutants step by step into intermediates of the central intermediary metabolism, for example, 
Citation: Olajire AA, Essien JP (2014) Aerobic Degradation of Petroleum Components by Microbial Consortia. J Pet Environ Biotechnol 5: 195. doi:10.4172/2157-7463.1000195

the tricarboxylic acid cycle. Biosynthesis of cell biomass occurs from the central precursor metabolites, for example, acetyl-CoA, succinate and pyruvate. Sugars required for various biosyntheses and growth are synthesized by gluconeogenesis.

Aliphatic hydrocarbons: Alkanes, a major group in crude oil, are readily biodegraded in the marine and non-marine environments. Oxidation of alkanes is classified as being terminal or sub-terminal. The degradation of alkanes of medium chain length by Pseudomonas putida containing the OCT plasmid is initiated by alkane hydroxylase [85,96-98]. This enzyme consists of three components: the membranebound oxygenase component and two soluble components called rubredoxin and rubredoxin reductase. The catalytic centre of the oxygenase component contains a dinuclear iron cluster which is also found in other enzymes such as methane monooxygenase and ribonucleotide reductase $[96,99]$. In P. putida (OCT), oxidation of the methyl group of alkanes by alkane hydroxylase yields alkanols that are further oxidized by a membrane-bound alcohol dehydrogenase to alkanals. The alkanals are subsequently transformed to fatty acids and then to acyl CoA by aldehyde dehydrogenase and acyl-CoA synthetase, respectively (Scheme 1) [99]. An alkane degrading pathway yielding secondary alcohols has also been reported. In this pathway, alkanes are oxidized by monooxygenase to secondary alcohols, then to ketones, and finally to fatty acids (Scheme 1) $[100,101]$. In Acinetobacter strain $\mathrm{M}-1$, alkanes are transformed to alkyl peroxides, and these molecules would be further metabolized to the corresponding aldehyde. The first enzyme involved in this pathway contains $\mathrm{FAD}^{+}$and $\mathrm{Cu}^{2+}$ as prosthetic groups (Scheme 1) [54,102].

Many yeast species, e.g. Candida maltosa, Candida tropicalis and Candida apicola, were investigated for use with alkanes [103,104]. The first step of alkane degradation (terminal hydroxylation) and of $\omega$ - hydroxylation is catalyzed by $\mathrm{P} 450$ monooxygenase. The alcohols thus formed are processed by fatty alcohol oxidase and fatty aldehyde dehydrogenase. The P450 enzyme from some yeast strains can catalyze not only the terminal hydroxylation of long-chain alkanes and the $\omega$-hydroxylation of fatty acids, but also the subsequent two steps to yield fatty acids and $\alpha, \omega$-dioic acids (Scheme 1) [104,105]. Catabolic pathways for the degradation of branched alkanes have been elucidated for a few bacteria; for example, Rhodococcus strain BPM 1613 degraded phytane (2,6,10,14-tetramethylhexadecane), norpristane (2,6,10-trimethylpentadecane) and farnesane

Terminal oxidation of $\boldsymbol{n}$-Alkanes
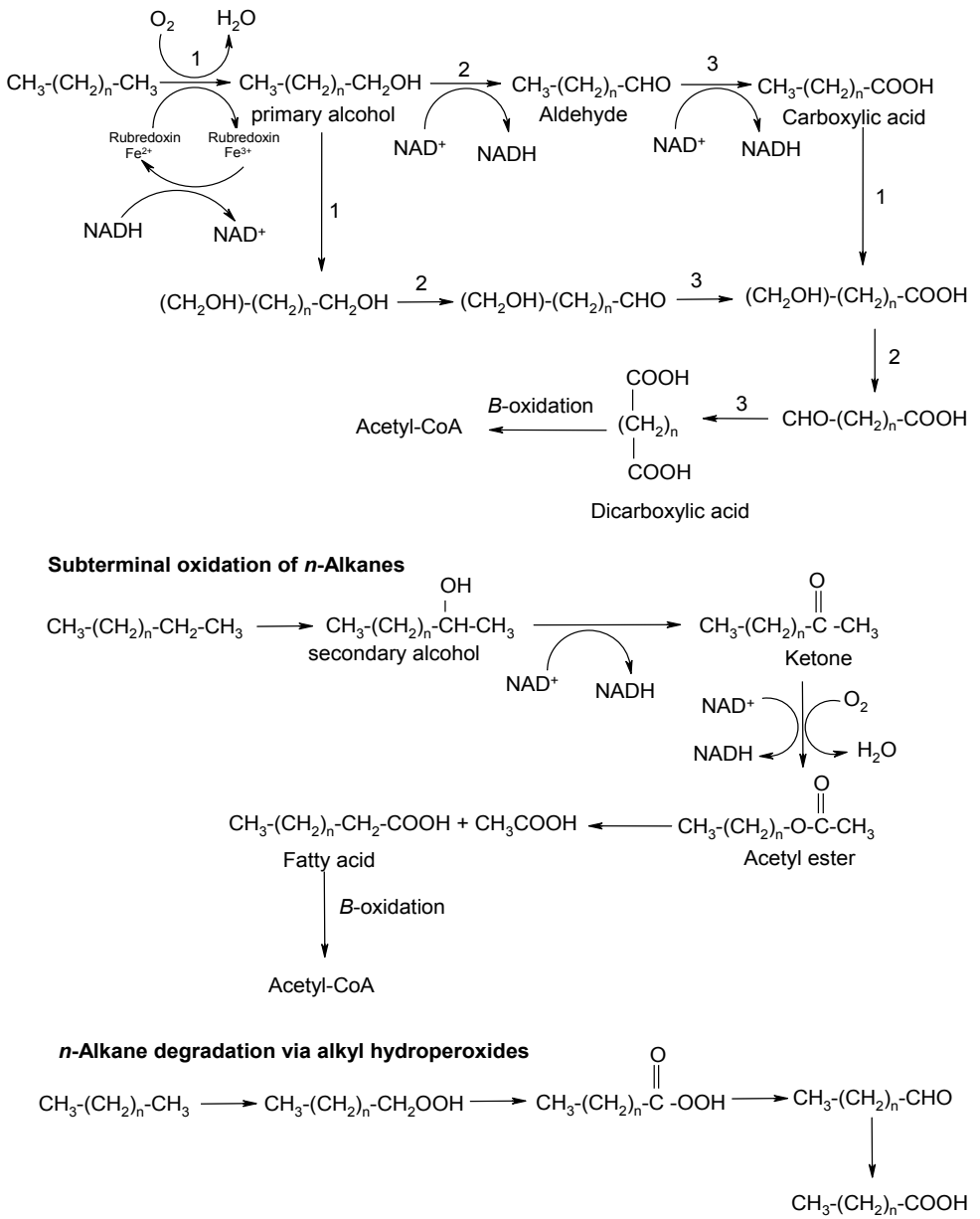

Scheme 1: Peripheral aerobic pathways of $n$-alkane degradation.

The main pathway is the terminal oxidation to fatty acid. $\alpha$-and $\omega$-hydroxylation is catalysed by the same set of enzymes. With bacteria, steps $1,2,3$ are catalysed by alkane monooxygenase, fatty alcohol dehydrogenase and fatty aldehyde dehydrogenase, respectively. With yeast, step 1 is catalysed by $P 450$ monooxygenase, while steps 2 and 3 are catalysed either by fatty alcohol oxidase and fatty aldehyde dehydrogenase, respectively; or by the P450 monooxygenase involved in step 1 . 
Citation: Olajire AA, Essien JP (2014) Aerobic Degradation of Petroleum Components by Microbial Consortia. J Pet Environ Biotechnol 5: 195. doi:10.4172/2157-7463.1000195

Page 6 of 22

(2,6,10-trimethyldodecane) via $\beta$-oxidation [96,106]. $\beta$-Oxidation of the fatty acids results in the formation of acetyl-CoA. Alkanes with an uneven number of carbon atoms are degraded to propionyl-CoA, which is in turn carboxylated to methylmalonyl-CoA and further converted to succinyl-CoA. The sub-terminal oxidation occurs with lower $\left(\mathrm{C}_{3}-\right.$ $\mathrm{C}_{6}$ ) and longer alkanes with the formation of a secondary alcohol and subsequent ketone (Scheme 1) [95]. Branching, in general, reduces the rate of biodegradation. Methyl side groups do not drastically decrease the biodegradability, whereas complex branching chains, e.g., the tertiary butyl group, hinder the action of the degradative enzymes [95]. Al-Mueini et al. [107] have reported the isolation of an extremely halophilic actino- mycete, Actinopolysporasp. DPD1 from an oil production site in the Sultanate of Oman and was shown to degrade $n$-alkanes (pentadecane, eicosane, pentacoase) and fluorine. The organism efficiently degraded pentadecane (100\% in 4 days) and eicosane ( $80 \%$ in 10 days). Degradation of longer chain alkanes such as pentacosane $\left(\mathrm{C}_{25} \mathrm{H}_{52}\right)$ proceeded at much slower rate resulting in only $15 \%$ degradation in 2 weeks and no triacontane $\left(\mathrm{C}_{30} \mathrm{H}_{62}\right)$ was degraded even after 20 days of incubation. Sass et al. [108] isolated a strain DS-1, closely related to Bacillus aquimaris from Discovery deep-sea hypersaline anoxic sediment that grew using $n$-alkanes ( $n$-dodecane and $n$-hexadecane) as the sole sources of carbon. Mnif et al. [26,32] isolated Halomonas sp. strain C2SS100 and Pseudomonas sp.strain C450R on the basis of their ability to degrade crude oil also degraded hexadecane as the sole carbon source. Dastgheib et al. [109] have isolated a halotolerant Alcanivorax sp. strain Qtet3 from tetracosane degrading enrichments obtained from a hydrocarbon contaminated soils from Qom location in Iran. Strain Qtet3 degrades a wide range of $n$-alkanes (from $\mathrm{C}_{10}$ to $\mathrm{C}_{34}$ ) with considerable growth on $\mathrm{C}_{14}$ and $\mathrm{C}_{16}$. Strain Qtet3 completely degraded tetracosane $\left(\mathrm{C}_{24} \mathrm{H}_{50}\right)$ as the sole carbon source in 20 days. In addition, the organism also degrades phytane and pristine, but not aromatic hydrocarbons such as naphthalene, phenanthrene, pyrene, and anthracene. Also, two Marinobacters, M. sedimentalis and M. falvimaris isolated on the basis of their ability to grow on crude oil from hypersaline Sabkhas in Kuwait also utilized Tween 80 and a wide range of individual aliphatic hydrocarbons $\left(\mathrm{C}_{9}-\mathrm{C}_{40}\right)$ as carbon sources [36]. Tapilatu et al. [110] have reported the isolation of several strains of archaea that degrade $n$-alkanes (heptadecane and eicosane) from a shallow crystallizer pond (Camargue, France) with no known contamination history. Of these isolates, strain, MSNC2 was closely

\begin{tabular}{|c|c|c|c|}
\hline Hydrocarbon & Structure & Degrader & References \\
\hline Octane & $\mathrm{C}_{8} \mathrm{H}_{18}$ & $\begin{array}{l}\text { Rhodococcus sp. Arthrobacter sp. } \\
\text { Bacillus sp. }\end{array}$ & Plotnikova et al. $[139,140]$ \\
\hline Decane & $\mathrm{C}_{10} \mathrm{H}_{22}$ & Bacillus sp strain $D H T$ & Kumar et al. [31] \\
\hline Tetradecane & $\mathrm{C}_{14} \mathrm{H}_{30}$ & EH4 (Haloarcula vallismortis) & Bertrand et al. [227] \\
\hline \multirow{2}{*}{ Pentadecane } & \multirow{2}{*}{$\mathrm{C}_{15} \mathrm{H}_{32}$} & Actinopolyspora sp. & Al-Mueini et al. [107] \\
\hline & & Marinobacter aquaeolei & Huu et al. [27] \\
\hline \multirow{7}{*}{ Hexadecane } & \multirow{7}{*}{$\mathrm{C}_{16} \mathrm{H}_{34}$} & Enrichment, Great Salt Lake, Utah & Ward and Brock [228] \\
\hline & & EH4 (Haloarcula vallismortis) & Bertrand et al. [227] \\
\hline & & Marinobacter hydrocarbonoclasticus & Gauthier et al. [229] \\
\hline & & Marinobacter aquaeolei & Huu et al. [27] \\
\hline & & Bacillus sp strain DHT & Kumar et al. [31] \\
\hline & & Strain DS1 & Sass et al. [108] \\
\hline & & Halomonas sp C2SS100 Pseudomonas sp. C450R & Mnif et al. [26] \\
\hline \multirow{3}{*}{ Octadecane } & \multirow{3}{*}{$\mathrm{C}_{18} \mathrm{H}_{38}$} & Microbial mats & Abed et al. [230] \\
\hline & & Haloferax sp. Halobacterium sp. & \multirow{2}{*}{ Al-Mailem et al. [111] } \\
\hline & & Halococcus sp. & \\
\hline Heptadecane & $\mathrm{C}_{17} \mathrm{H}_{36}$ & Haloarcula sp. Haloferax sp. & Tapilatu et al. [110] \\
\hline \multirow{5}{*}{ Pristane } & \multirow{5}{*}{$\mathrm{C}_{19} \mathrm{H}_{40}$} & EH4 (Haloarcula vallismortis) & Bertrand et al. [227] \\
\hline & & Marinobacter hydrocarbonoclasticus & Gauthier et al. [229] \\
\hline & & Marinobacter aquaeolei & Huu et al. [27] \\
\hline & & Microbial mats, Arabian Gulf coast, Saudi Arabia & Abed et al. [230] \\
\hline & & Alcanivorax sp. Qtet3 & Dastgheib et al. [109] \\
\hline \multirow{4}{*}{ Eicosane } & \multirow{4}{*}{$\mathrm{C}_{20} \mathrm{H}_{42}$} & EH4 (Haloarcula vallismortis) & Bertrand et al. [227] \\
\hline & & Marinobacter hydrocarbonoclasticus & Fernandez-Linares et al. [231] \\
\hline & & Actinopolyspora sp. DPD1 & Al-Mueini et al. [107] \\
\hline & & Haloarcula sp. Haloferax sp. & Tapilatu et al. [110] \\
\hline Phytane & $\mathrm{C}_{20} \mathrm{H}_{42}$ & Alcanivorax sp. strain Qtet3 & Dastgheib et al. [109] \\
\hline \multirow{2}{*}{ Heneicosane } & \multirow{2}{*}{$\mathrm{C}_{21} \mathrm{H}_{44}$} & EH4 (Haloarcula vallismortis) & Bertrand et al. [227] \\
\hline & & Marinobacter hydrocarbonoclasticus & Gauthier et al. [229] \\
\hline Tetracosane & $\mathrm{C}_{24} \mathrm{H}_{50}$ & Alcanivorax sp. strain Qtet3 & Dastgheib et al. [109] \\
\hline Pentacosane & $\mathrm{C}_{25} \mathrm{H}_{52}$ & Actinopolyspora sp. DPD1 & Al-Mueini et al. [107] \\
\hline \multirow{5}{*}{ n-Alkane } & $\mathrm{C}_{10}-\mathrm{C}_{30}$ & Halobacterium sp & Kulichevskaya et al. [232] \\
\hline & $\mathrm{C}_{10}-\mathrm{C}_{34}$ & $\begin{array}{c}\text { Haloferax sp. Halobacterium sp. } \\
\text { Halococcus sp. }\end{array}$ & Al-Mailem et al. [111] \\
\hline & $\mathrm{C}_{10}-\mathrm{C}_{34}$ & Alcanivorax sp. strain Qtet3 & Dastgheib et al. [109] \\
\hline & \multirow{2}{*}{$\mathrm{C}_{9}-\mathrm{C}_{40}$} & Marinobacter sedimentalis & \multirow[t]{2}{*}{ Al-Mailem et al. [36] } \\
\hline & & Marinobacter falvimaris & \\
\hline
\end{tabular}

Table 2: Microorganisms having degradation potential for aliphatic hydrocarbons. 
related to Haloarcula and strains, MSNC4, MSNC14, and MSNC16 to Haloferax. In addition, strain MSNC14 also degraded phenanthrene. Three extremely halophilic archaeal strains, Haloferax, Halobacterium and Halococcus isolated on the basis of crude oil utilization also degraded $n$-alkanes and mono and polyaromatic compounds as the sole sources of carbon and energy [111]. Overall, studies reveal that both bacteria and archaea have the capacity to metabolize $n$-alkanes with varying chain lengths (Table 2 ).

Alicyclic hydrocarbons: Cycloalkanes representing minor components of mineral oil are relatively recalcitrant to microbial attack [95]. The absence of an exposed terminal methyl group as in $n$-alkanes complicates the primary attack. A few species are able to use cyclohexane as sole carbon source. Cycloalkanes, including condensed cycloalkanes are degraded by a co-oxidation mechanism [96,101,112]. The mechanism of cyclohexane degradation is shown in Scheme 2. The formation of a cyclic alcohol and a ketone has been observed [101]. A monooxygenase introduces an oxygen into the cyclic ketone, and the cyclic ring is cleaved (Scheme 2).

Aromatic compounds: A multitude of catabolic pathways for the degradation of aromatic compounds have been elucidated; for example, toluene is degraded by bacteria along five different pathways. On the pathway encoded by the TOL plasmid, toluene is successively degraded to benzyl alcohol, benzaldehyde and benzoate, which is further transformed to the TCA cycle intermediates [13]. The first step of toluene degradation with P. putida $\mathrm{F} 1$ is the introduction of two hydroxyl groups to toluene, forming cis-toluene dihydrodiol. This intermediate is then converted to 3-methylcatechol [113]. With Pseudomonas mendocina $\mathrm{KR} 1$, toluene is converted by toluene 4-monooxygenase to $p$-cresol, this being followed by $p$-hydroxybenzoate formation through oxidation of the methyl side chain [13,114]. With Pseudomonas pickettii $\mathrm{PKO} 1$, toluene is oxidized by toluene 3-monooxygenase to $m$-cresol, which is further oxidized to 3-methylcatechol by another monooxygenase [13,114]. With Bukholderia cepacia G4, toluene is metabolized to $o$-cresol by toluene 2-monooxygenase, this intermediate being transformed by another monooxygenase to 3-methylcatechol [13].

Burkholderia sp. strain JS150 is unique in using multiple pathways for the metabolism of toluene (Scheme 3) [115].

The oxygenolytic cleavage of the aromatic ring occurs via $o$ - or $m$-cleavage [116]. The metabolism of a wide spectrum of aromatic compounds by one species requires the metabolic isolation of intermediates into distinct pathways. The key enzymes of the degradation of aromatic substrates are induced and synthesized in appreciable amounts only when the substrate or structurally related compounds are present. Scheme 4 shows the pathways of the oxygenolytic ring cleavage of phenol to intermediates of the central metabolism. At the branch-point, catechol is either oxidized by the intradiol $o$-cleavage, or the extradiol $m$-cleavage. Both ring cleavage reactions are catalyzed by specific dioxygenases. The product of the o-cleavage - cis, cismuconate - is transferred to the unstable enollactone, which is in turn hydrolyzed to oxoadipate. This dicarboxylic acid is activated by transfer to CoA, followed by the thiolytic cleavage to acetyl-CoA and succinate. Protocatechuate is metabolized by a homologous set of enzymes. The additional carboxylic group is decarboxylated and, simultaneously, the double bond is shifted to form oxoadipate enollactone [95].

The oxygenolytic $m$-cleavage yields 2 - hydroxymuconic semialdehyde, which is metabolized by the hydrolytic enzymes to formate, acetaldehyde, and pyruvate (Scheme 4). These are then utilized in the central metabolism. In general, a wealth of aromatic substrates is degraded by a limited number of reactions, which include hydroxylation, oxygenolytic ring cleavage, isomerization, and hydrolysis [117-120]. The inducible nature of the enzymes and their substrate specificity enable bacteria with a high degradation potential, e.g., Pseudomonads and Rhodococci, to adapt their metabolism to the effective utilization of substrate mixtures in polluted soils and to grow at a high rate.

Several studies have successfully isolated bacteria and archaea that degrade oxygenated aromatics. Table 3 lists organisms that degrade oxygenated hydrocarbons. Woolard and Irvine [121] showed that a halophile isolated from a mixed culture obtained from a saltern at GSL Utah readily degraded phenol. Alva and Peyton [122] isolated a haloalkaliphile, Halomonas campisalis near Soap Lake in central Washington and showed that this organism degraded phenol and catechol as the sole sources of carbon at $\mathrm{pH}$ 8-11. A Gram-positive halophilic bacterium, Thalassobacillus devorans isolated from an enrichment culture developed from saline habitats in southern Spain was shown to degrade phenol [123]. The strain C5, closely related to Geobacillus pallidus isolated from a tyrosol-utilizing enrichment also degrades a variety of other oxygenated aromatic compounds including benzoic, p-hydroxybenzoic, protocatechuic, vanillic, p-hydroxyphenylacetic, 3,4-dihydroxyphenylacetic, cinnamic, ferulic, phenol, and $m$-cresol. However, no degradation of non-oxygenated hydrocarbons such as toluene, naphthalene, and phenanthrene was observed [33]. Recently, Bonfá et al. [124] have shown the degradation of phenol as the sole source of carbon by Halomonas organivorans, Arhodomonas aquaeolei, and Modicisalibacter tunisiensis isolated from different hypersaline environments.

Many reports also exist on the ability of halophilic and halotolerant organisms to degrade benzoates. The halotolerant, Pseudomonas



Scheme 2: Peripheric metabolic pathway for the aerobic degradation of cyclohexane.

1, cyclohexane monooxygenase; 2, cyclohexanol dehydrogenase; 3, cyclohexanone monooxygenase; 4, $\varepsilon$-caprolactone hydrolase. 


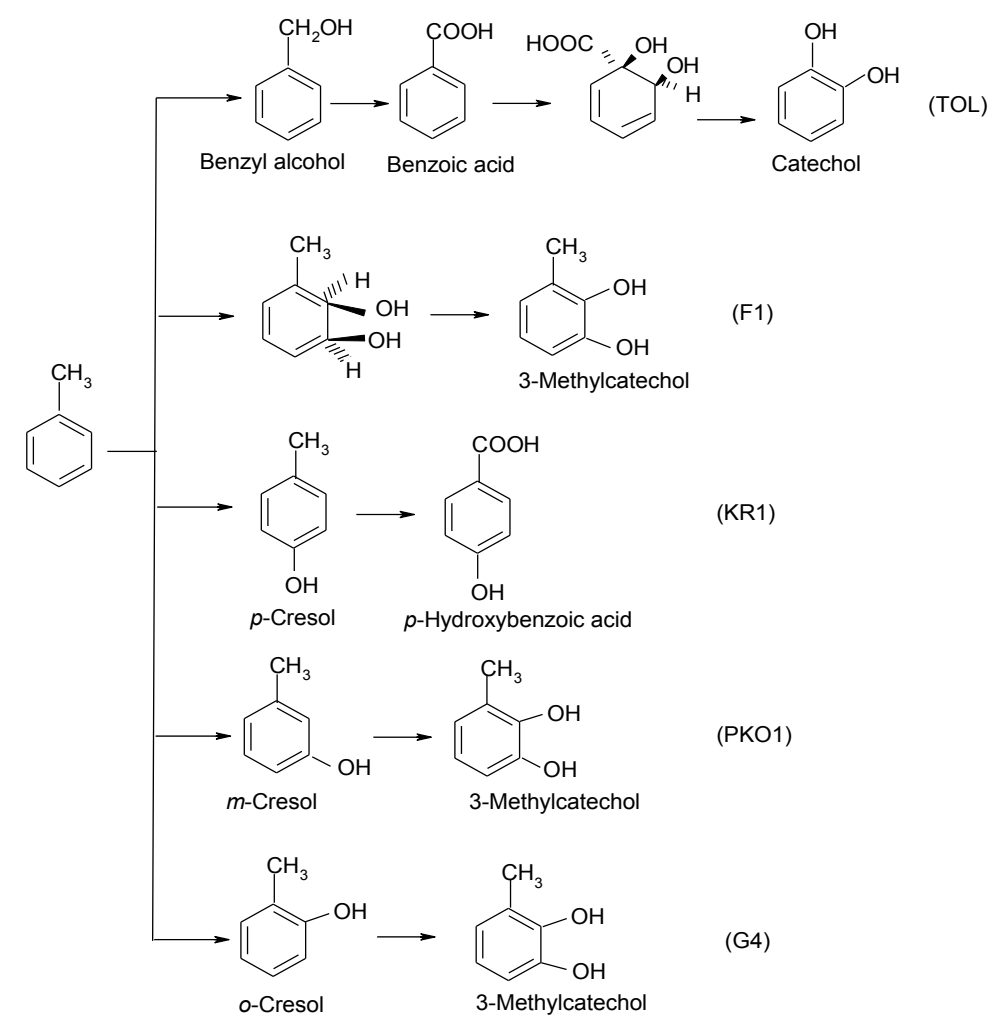

Scheme 3: Divergent pathways for aerobic degradation of toluene.

The pathways from top to bottom are found with P. putida (TOL), P. putida (F1), P. mendocina (KR1), P. pickettii (PKO1) and B. cepacia (G4), respectively.

halodurans (re-classified as Halomonas halodurans) degrades benzoic acid [125]. Garcia et al. [126,127] have isolated several strains of Halomonas spp. including the Halomonas organivorans from water and sediment of salterns and hypersalines oils collected in different part of the Southern Spain. These isolates degraded a wide range of aromatic compounds including benzoic acid, $p$-hydroxy benzoic acid, phenol, salicylic acid, $p$-aminosalicylic acid, phenylacetic acid, phenylpropionic acid, cinnamic acid, ferulic acid, and $p$-coumaric acid as the sole sources of carbon. Abdelkafi et al. [128] have reported the isolation of a p-coumaric acid degrading Halomonas strain IMPC from a $p$-coumaric acid degrading enrichment culture obtained from a Tableolive fermentation rich in aromatic compounds. This strain converted $p$-coumaric acid to $p$-hydroxybenzaldehyde, $p$-hydroxybenzoic acid, and then to protocatechuic acid prior to ring cleavage. In addition, the strain also degraded other lignin-related compounds such as cinnamic acid, $m$-coumaric acid, $m$ - and $p$-methoxy cinnamic acid, $m$ and $p$-methylcinnamic acid, and ferulic acid to their corresponding benzoic acid derivatives. Oie et al. [129] have studied the degradation of benzoate and salicylate by Halomonas campisalis isolated from an alkaline Soap Lake. This study showed that the organism degraded benzoate and salicylate to catechol and then to cis, cis-muconate thus indicating degradation via the ortho-cleavage pathway. Kim et al. [130] have isolated a Chromohalobacter sp. strain HS-2 from salted fermented clams that degrades benzoate and $p$-hydroxybenzoate as the sole carbon and energy sources.

Cuadros-Orellana et al. [131] have reported the isolation of 10 halophilic archaea from Dead Sea that degrades $p$-hydroxybenzoic acid as the sole carbon and energy source. In addition, strain L1, a member of the unclassified Halobacteriaceae family of the phylum, Euryarchaeota also degrades benzoic acid to gentisate. Erdogmus et al. [132] reported the ability of many archaeal strains belonging to Halobacterium, Haloferax, Halorubrum, and Haloarcula group to degrade $p$-hydroxybenzoic acid. These studies clearly demonstrate that archaea that metabolize $p$-hydroxybenzoic are wide spread in the environment. Among bacteria, Halomonas spp. has been frequently reported for their ability to degrade phenolics and benzoates and only few reports exist on their potential to degrade non-oxygenated hydrocarbons.

The most abundant hydrocarbons in produced water are the onering aromatic hydrocarbons, benzene, toluene, ethyl benzene, and xylenes (BTEX) and low molecular weight saturated hydrocarbons [133]. Benzene is a category A carcinogen. Leakage from produced water storage tanks, pipelines, spills, and seepage from surface contaminated sites can cause major BTEX contamination [10]. BTEX are relatively highly soluble in water and hence can contaminate large volumes of ground water. Although there have been many recent reports on the biodegradation of non-oxygenated hydrocarbons, only few reports exist on the biodegradation of BTEX compounds (Table 4). Nicholson and Fathepure $[134,135]$ have reported the degradation of BTEX in microcosms established with soil samples from an oilfield and from an uncontaminated salt flat in Oklahoma. Hassan et al. [136] have reported the isolation of Alcanivorax sp. HA03 from soda lakes in Wadi E1Natrun capable of degrading benzene, toluene, and chlorobenzene as the sole sources of carbon. This observation that Alcanivorax can also degrade aromatic compounds expands the metabolic capability of this group of organisms because Alcanivorax 
Citation: Olajire AA, Essien JP (2014) Aerobic Degradation of Petroleum Components by Microbial Consortia. J Pet Environ Biotechnol 5: 195. doi:10.4172/2157-7463.1000195

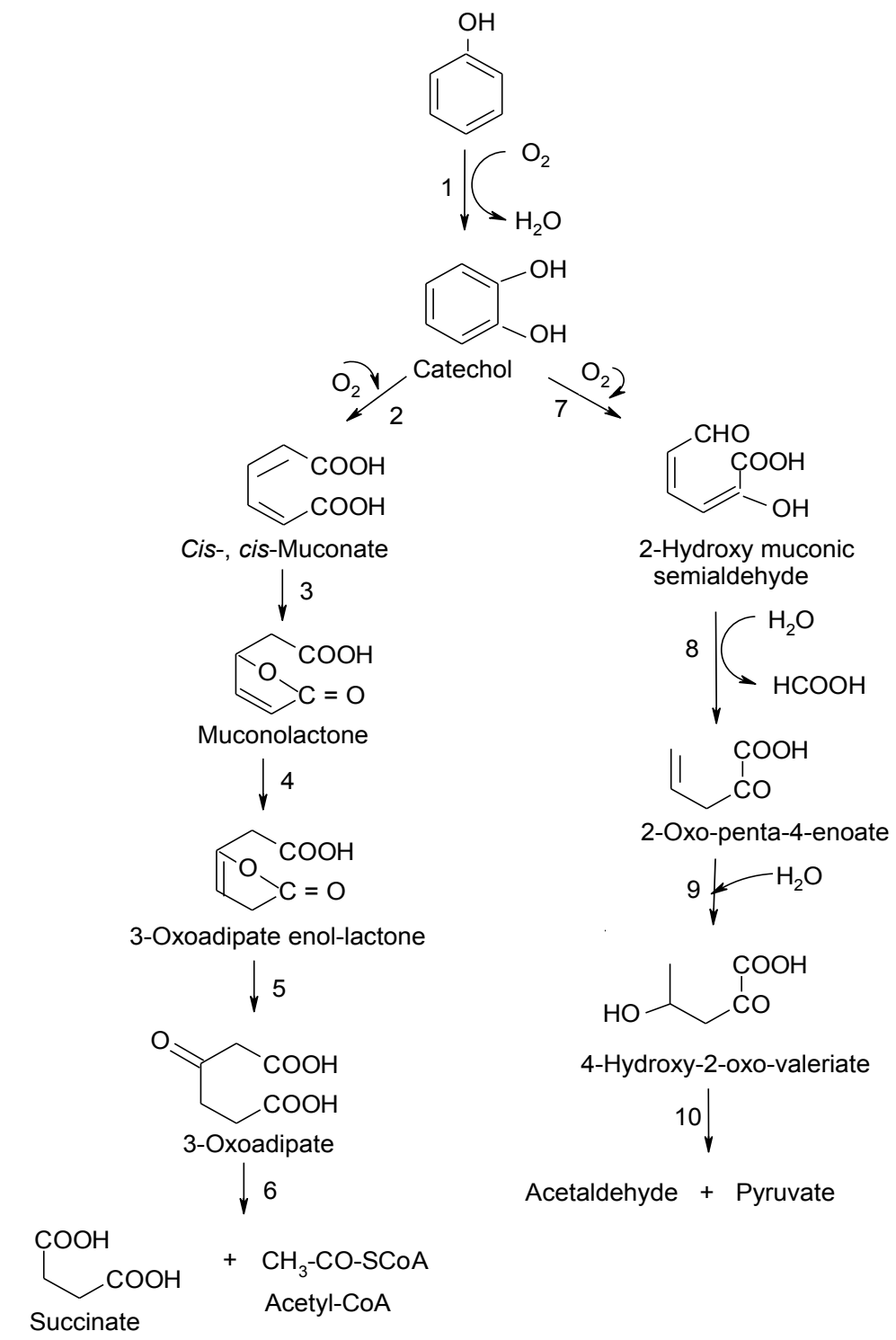

Scheme 4: The two alternative pathways of aerobic degradation of phenol: o- and $m$ - cleavage. 1, phenol monoxygenase; 2, catechol 1,2-dioxygenase; 3, muconate lactonizing enzyme; 4, muconolactone isomerase; 5, oxoadipate enol-lactone hydrolase; 6, oxoadipate succinyl- CoA transferase; 7, catechol 2,3-dioxygenase; 8, hydroxymuconic semialdehyde hydrolase; 9, 2-oxopent-4- enoic acid hydrolase; 10, 4-hydroxy-2-oxovalerate aldolase.

are primarily known for their ability to degrade aliphatic hydrocarbons. Degradation of benzene was also reported in archaea. For example, the crude oil degrading Haloferax, Halobacterium, and Halococcus isolated from a hypersaline Arabian Gulf coast degraded benzene as the sole source of carbon [111].The complete degradation of PAHs requires a community of microorganisms. PAHs are taken up by microorganisms and are activated in aerobic metabolism by insertion of two oxygen atoms by bacteria and green algae to produce either cis-dihydrodiols or phenols [137]. Simple PAHs such as naphthalene, biphenyl and phenanthrene are readily degraded aerobically. The degradation of these compounds is generally initiated by dihydroxylation of one of the $\mathrm{PAH}$ rings, this being followed by cleavage of the dihydroxylated ring. Ring hydroxylation is catalyzed by a multi-component dioxygenase which consists of a reductase, a ferredoxin, and an iron sulphur protein, while ring cleavage is generally catalyzed by an iron-containing metacleavage enzyme. The carbon skeleton produced by the ring-cleavage reaction is then dismantled, before cleavage of the second aromatic ring (Scheme 5) [138].

Plotnikova et al. [139,140] have isolated Pseudomonas sp., Rhodococcus sp., Arthrobacter sp., and Bacillus sp. from soil and sediment contaminated with waste generated by chemical and saltproducing plants. All these isolates degraded naphthalene and salicylate as the sole carbon sources. In addition, some of these organisms also grew on phenanthrene, biphenyl, $o$-phthalate, gentisate, octane, and phenol as the sole sources of carbon. Zhao et al. [141] have shown the degradation of phenanthrene by a halophilic bacterial consortium developed from soil samples collected from the Shengli Oilfield in China. Phenanthrene was completely degraded by the enrichment in 8 days. Molecular analysis of the enrichment culture indicated the presence of alpha and gamma-proteobacteria including members of the genus Halomonas, Chromohalobacter, Alcanivorax, Marinobacter, 
Citation: Olajire AA, Essien JP (2014) Aerobic Degradation of Petroleum Components by Microbial Consortia. J Pet Environ Biotechnol 5: 195. doi:10.4172/2157-7463.1000195

Page 10 of 22

\begin{tabular}{|c|c|c|c|}
\hline Hydrocarbon & Structure & Degrader & References \\
\hline Phenol & & $\begin{array}{l}\text { Halophilic isolate } \\
\text { Halomonas sp. } \\
\text { Candida tropicals Halomonas campisalis Halomonas } \\
\text { organivorans Thelassobacillusdevorans Arthrobacter sp. } \\
\text { Strain C5 } \\
\text { Halomonas organivorans, Arhodomonas aquaeolei, } \\
\text { Modicisalibacter tunisiensis }\end{array}$ & $\begin{array}{l}\text { Woolard and Irvine [121] Hinteregger and Streischsberg [233] } \\
\text { Bastos et al. [234] } \\
\text { Alva and Peyton [122] } \\
\text { Garcia et al. [126,127] } \\
\text { Garcia et al. [123] } \\
\text { Plotnikova et al. [140] Chamkha et al. [33] } \\
\text { Bonfá et al. [124] }\end{array}$ \\
\hline \multirow[t]{2}{*}{ Benzoate } & & $\begin{array}{l}\text { Halomonas halodurans } \\
\text { Haloferax sp. D1227 } \\
\text { Halomonas sp. Halomonas organivorans Halomonas } \\
\text { campisalis Chromohalobacter sp. strainHS-2 } \\
\text { Haloferax sp. Strain C5 } \\
\text { Halomonas elongate Halomonas eurihalina Marinobacter } \\
\text { lipolyticus }\end{array}$ & $\begin{array}{l}\text { Rosenberg [125] } \\
\text { Emerson et al. [235] Kleinsteuber et al. [236] } \\
\text { Garcia et al. [126,127] } \\
\text { Oie et al. [129] } \\
\text { Kim et al. [130] } \\
\text { Bonfá et al. [144] } \\
\text { Chamkha et al. [33] } \\
\text { Garcia et al. [123] }\end{array}$ \\
\hline & & $\begin{array}{l}\text { Pseudomonas sp. Rhodococcus } \\
\text { sp. Arthrobacter sp. Bacillus } \\
\text { sp. } \\
\text { Halomonas organivorans Halomonas organivorans, } \\
\text { Salinicoccus roseus Halomonas venusta Halomonas } \\
\text { alimentaria Halomonas campisalis Bacillus sp. strainDHT } \\
\text { Haloferax sp. }\end{array}$ & $\begin{array}{l}\text { Plotnikova et al. [139] } \\
\text { Garcia et al. [126] Garcia et al. [127] } \\
\text { Oie et al. [129] } \\
\text { Kumar et al. [31] Bonfá et al. [144] }\end{array}$ \\
\hline $\begin{array}{l}\text { O- } \\
\text { Phthalate }\end{array}$ & & $\begin{array}{l}\text { Rhodococcus sp. Arthrobacter } \\
\text { sp. Bacillus sp. }\end{array}$ & Plotnikova et al. $[139,140]$ \\
\hline Gentisate & & $\begin{array}{l}\text { Rhodococcus sp. Arthrobacter } \\
\mathrm{sp} \text {. Bacillus sp. }\end{array}$ & Plotnikova et al. [139] \\
\hline $\begin{array}{l}\text { 4- } \\
\text { Hydroxy- } \\
\text { benzoate }\end{array}$ & & $\begin{array}{l}\text { Haloarcula sp. strainD1, } \\
\text { Halomonas organivorans Halomonas elongate Halophilic } \\
\text { archaeal strains Chromohalobacter sp. strainHS-2 } \\
\text { Strain C5 } \\
\text { Haloferax sp. } \\
\text { Halobacterium sp. Haloferax sp. Halorubrum sp. Haloarcula sp. }\end{array}$ & $\begin{array}{l}\text { Fairley et al. [237] } \\
\text { Garcia et al. [126] } \\
\text { Garcia et al. [127] } \\
\text { Cuadros-Orellana et al. [131,238] } \\
\text { Kim et al. [130] } \\
\text { Chamkha et al. [33] } \\
\text { Bonfá et al. [144] } \\
\text { Erdogmus et al. [132] }\end{array}$ \\
\hline $\begin{array}{l}\text { Phenyl } \\
\text { propionic acid }\end{array}$ & & $\begin{array}{l}\text { Haloferax sp. D1227 } \\
\text { Halomonas organivorans Halomonas elongata Halomonas } \\
\text { glaciei Halomonas organivorans }\end{array}$ & $\begin{array}{l}\text { Emerson et al. [235]; Fu and Oriel [239] } \\
\text { Garcia et al. [123] } \\
\text { Garcia et al. [126,127] }\end{array}$ \\
\hline $\begin{array}{l}\text { Cinnamic } \\
\text { acid }\end{array}$ & & $\begin{array}{l}\text { Haloferax sp. D1227 } \\
\text { Halomonas organivorans Halomonas organivorans Halomonas } \\
\text { salina/Halomonashalophila Halomonas elongate Halomonas } \\
\text { strain IMPC Strain C5 }\end{array}$ & $\begin{array}{l}\text { Emerson et al. [219] } \\
\text { Garcia et al. [114] } \\
\text { Garcia et al. [115] } \\
\text { Abdelkafi et al. [128] } \\
\text { Chamkha et al. [32] }\end{array}$ \\
\hline $\begin{array}{l}p \text { - } \\
\text { Coumaric acid }\end{array}$ & & $\begin{array}{l}\text { Halomonas organivorans } \\
\text { Halomonas organivorans Halomonas salina Chromohalobacter } \\
\text { israelensis Halomonas strain IMPC } \\
\text { Strain C5 }\end{array}$ & $\begin{array}{l}\text { Garcia et al. [112] } \\
\text { Garcia et al. [113] } \\
\text { Abdelkafi et al. [128] } \\
\text { Chamkha et al. [33] }\end{array}$ \\
\hline $\begin{array}{l}\text { Ferulic } \\
\text { acid }\end{array}$ & & $\begin{array}{l}\text { Halomonas organivorans } \\
\text { Halomonas strain IMPC Halomonas elongate Strain C5 }\end{array}$ & $\begin{array}{l}\text { Garcia et al. [126] } \\
\text { Abdelkafi et al. [128] } \\
\text { Garcia et al. [123] } \\
\text { Chamkha et al. [33] }\end{array}$ \\
\hline
\end{tabular}

Table 3: Microorganisms having degradation potential for phenolics and benzoates. 
Citation: Olajire AA, Essien JP (2014) Aerobic Degradation of Petroleum Components by Microbial Consortia. J Pet Environ Biotechnol 5: 195. doi:10.4172/2157-7463.1000195

Page 11 of 22

\begin{tabular}{|c|c|c|c|}
\hline Hydrocarbon & Structure & Degrader & References \\
\hline Benzene & & $\begin{array}{l}\text { Enrichment, Oilfield Oklahoma } \\
\text { Enrichment, Great Salt Plains, Oklahoma } \\
\text { Planococcus sp. strainZD22 } \\
\text { Arhodomonas sp. strainSeminole } \\
\text { Enrichment, Rozel Point, Great Salt } \\
\text { Lake, Utah } \\
\text { Arhodomonas sp. strainRozel } \\
\text { Marinobacter vinifirmus, M. hydrocarbonoclasticus Haloferax } \\
\text { sp.Halobacterium sp. Halococcus sp. } \\
\text { Alcanivorax sp.HA03 } \\
\text { Marinobacter sedimentalis, } \\
\text { Marinobacter falvimaris }\end{array}$ & $\begin{array}{l}\text { Nicholson and Fathepure [134] } \\
\text { Nicholson and Fathepure [135] } \\
\text { Li et al. [240] } \\
\text { Nicholson and Fathepure [241], Dalvi et al. [242] Sei } \\
\text { and Fathepure [243] } \\
\text { Azetsu et al. [244], Dalvi et al. [242] } \\
\text { Berlendis et al. [245] } \\
\text { Al-Mailem et al. [111] } \\
\text { Hassan et al. [136] } \\
\text { Al-Mailem et al. [36] }\end{array}$ \\
\hline Toluene & & $\begin{array}{l}\text { Enrichment, oilfield soil, Oklahoma } \\
\text { Enrichment, Great Salt Plains, Oklahoma } \\
\text { Planococcus sp. strainZD22 } \\
\text { Arhodomonas sp. strainSeminole } \\
\text { Enrichment, Rozel Point, Great Salt } \\
\text { Plains, Utah } \\
\text { Arhodomonas sp. strainRozel } \\
\text { Marinobacter vinifirmus, M.hydrocarbonoclasticus Haloferax sp. } \\
\text { Halobacterium sp. Halococcus sp. } \\
\text { Alcanivorax sp.HA03 3-15 }\end{array}$ & $\begin{array}{l}\text { Nicholson and Fathepure [134] } \\
\text { Nicholson and Fathepure [135] } \\
\text { Li et al. [240] } \\
\text { Nicholson and Fathepure [241], Dalvi et al. [242] } \\
\text { Sei and Fathepure [243] } \\
\text { Azetsu et al. [244], Dalvi et al. [242] } \\
\text { Berlendis et al. [245] } \\
\text { Al-Mailem et al. [111] } \\
\text { Hassan et al. [136] }\end{array}$ \\
\hline $\begin{array}{l}\text { Ethylbenze } \\
\text { ne }\end{array}$ & & $\begin{array}{l}\text { Enrichment, oilfield soil, Oklahoma } \\
\text { Planococcus sp. strainZD22 } \\
\text { Marinobacter vinifirmus, M.hydrocarbonoclasticus }\end{array}$ & $\begin{array}{l}\text { Nicholson and Fathepure [134] } \\
\text { Li et al. [240] } \\
\text { Berlendis et al. [245] }\end{array}$ \\
\hline Xylene & & $\begin{array}{l}\text { Enrichment, oilfield soil, Oklahoma } \\
\text { Planococcus sp. strainZD22 } \\
\text { Marinobacter vinifirmus, M.hydrocarbonoclasticus }\end{array}$ & $\begin{array}{l}\text { Nicholson and Fathepure [134] } \\
\text { Li et al. [240] } \\
\text { Berlendis et al. [245] }\end{array}$ \\
\hline
\end{tabular}

Table 4: Microorganisms having degradation potential for benzene, toluene, ethylbenzene and xylenes (BTEX).

Idiomarina, and Thalassospira. Dastgheib et al. [142] have obtained a mixed culture (Qphe-SubIV) consisting of Halomonas sp. and Marinobacter sp. from hydrocarbon contaminated saline soil collected from five different regions in Iran. These organisms degraded several PAHs including naphthalene, phenanthrene, anthracene, fluoranthene, fluorine, pyrene, benz[a]anthracene, and benzo[a]pyrene as the sole carbon sources. Recently, Al-Mailem et al. [36] have reported the ability of Marinobacter sedimentalis and Marinobacter falvimaris isolated from hypersaline sabkhas to degrade biphenyl, phenanthrene, anthracene and naphthalene as the sole sources of carbon and energy. More recently, Gao et al. [143] have isolated

Marinobacter nanhaiticus strain D15-8W from a phenanthrenedegrading enrichment obtained from sediment from the South China Sea. The strain D15-8W degrades naphthalene, phenanthrene or anthracene as the sole source of carbon. Bonfá et al. [144] have isolated several strains of Haloferax that degrade a mixture of the PAHs including naphthalene, anthracene, phenanthrene, pyrene and benzo[a] anthracene. Extremely halophilic archaeal strains of Haloferax, Halobacterium, and Halococcus isolated from a hypersaline coastal area of the Arabian Gulf not only degraded crude oil and $n$-octadecane as the carbon sources, but also grew on phenanthrene [111]. Erdogmu, s et al. [132] showed the degradation of naphthalene, phenanthrene and pyrene as the sole carbon sources by several archaeal strains including Halobacterium piscisalsi, Halorubrum ezzemoulense, Halobacterium salinarium, Haloarcula hispanica, Haloferax sp. Halorubrum sp. and Haloarcula sp. isolated from brine samples of Camalt Saltern in Turkey.
All these studies demonstrate the potential of bacteria and archaea to degrade PAHs (Table 5).

Numerous works have been done on the use of fungi for biodegradation of petroleum hydrocarbons [38,44,78,116,145]. Most filamentous fungi is unable to totally mineralize aromatic hydrocarbons; but only transform them into indirect products of lowered toxicity and increased susceptibility to decomposition with the use of bactetria. Among the filamentous fungi capable of aliphatic hydrocarbon biodegradation include Cladophialophoria and Aspergillus, whereas fungi belonging to Cunninghamella, Penicillimum, Fusarium and Aspergillus are capable of degrading aromatic hydrocarbons. PrenafelaBoldu et al. [2,116] have reported the use of Cladophialophoria sp. fungi in monoaromatic hydrocarbons (BTEX) mineralization. Their results showed that the decomposition is more dynamic for toluene, ethylbenzene and $\mathrm{m}$-xylene than for benzene. Common fungi with ability of biodegradation of aromatic compounds (BTEX, PAH) include Phanerochaete chrysosporum. This fungus produces extracellular enzymes (lignic peroxydase) that participate in decomposition of a lignic cell -wall in plants and in oxygenation of various xenobiotics. The microorganism transforms $\mathrm{PAH}$ into chinone derivative and later splits the aromatic ring of chinones with their complete mineralization in consecutive stages. Flayyih and AI- Jawhari [146] investigated the abilities of four fungi isolated from indigenously polluted soil to utilize petroleum hydrocarbon as their source. Of all the fungal isolates obtained in their study Aspergillus niger, Aspergillus fumigatus, Fusarium solani 
Citation: Olajire AA, Essien JP (2014) Aerobic Degradation of Petroleum Components by Microbial Consortia. J Pet Environ Biotechnol 5: 195. doi:10.4172/2157-7463.1000195
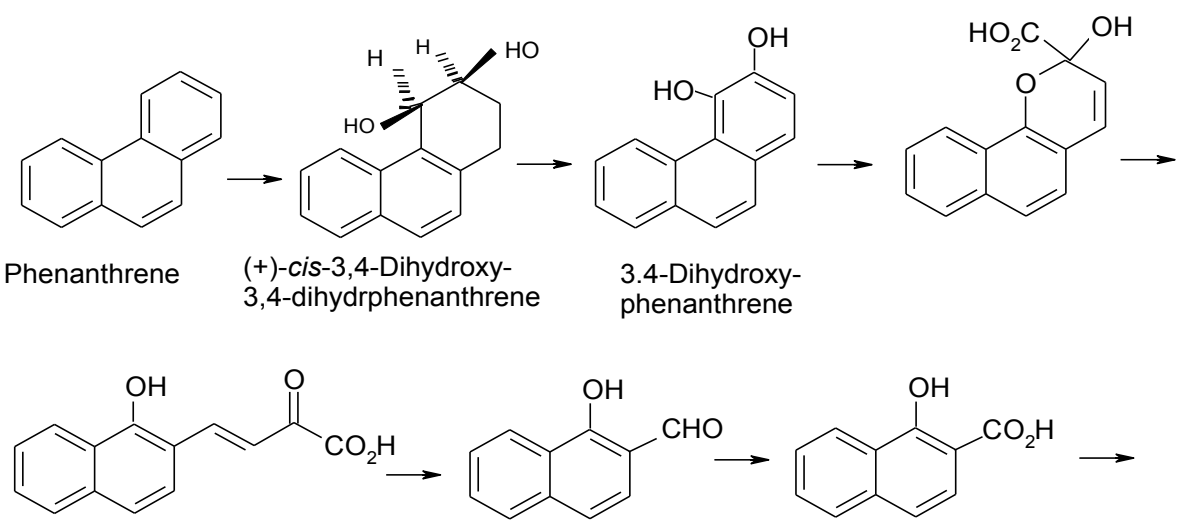

1-Hydroxy-2-naphthaldehyde

1-Hydroxy-2-naphthoate<smiles>CCC(=O)C(=O)/C=C/c1ccccc1C(=O)O</smiles>

trans-2'Carboxybenzal-pyruvate<smiles>O=Cc1ccccc1C(=O)O</smiles>

2-Carboxybenzaldehyde<smiles>O=C(O)c1ccccc1C(=O)O</smiles>

o-Phthalate<smiles>O=C(O)C1=C[C@H](O)[C@@H](O)C=C1C(=O)O</smiles>

4,5-Dihydr-4,5dihydroxyphthalate



4,5-Dihydroxyphthalate Protocatechuate B-carboxy-cis,cis- Y-carboxymuconolactone

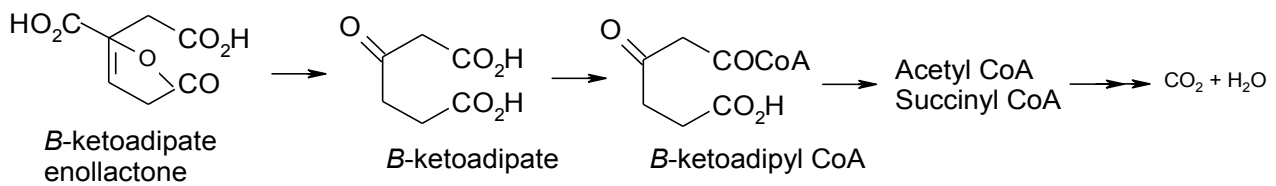

Scheme 5: Catabolic pathway for the aerobic degradation of phenanthrene with Nocardioides sp. KP7

\begin{tabular}{|c|c|c|c|}
\hline Hydrocarbon & Structure & Degrader & References \\
\hline Naphthalene & & $\begin{array}{l}\text { Micrococcus sp. Pseudomonas sp. } \\
\text { Alcaligenes sp. Pseudomonas sp. Rhodococcus sp. Arthrobacter sp. } \\
\text { Bacillus sp. } \\
\text { Bacillus sp strainDHT Haloferax sp. Halobacterium sp. Halococcus sp. } \\
\text { Haloferax spp. } \\
\text { Arthrobacter spp. SN17 } \\
\text { Mixed culture (Qphe-SubIV) Marinobacter sedimentalis Marinobacter falvimaris } \\
\text { Marinobacter nanhaiticus } \\
\text { Halobacterium piscisalsi, Halorubrum ezzemoulense, Halobacterium salinarium, } \\
\text { Haloarcula hispanica Haloferax } \\
\text { sp. Halorubrum sp. Haloarcula sp. }\end{array}$ & $\begin{array}{l}\text { Ashok et al. [246] } \\
\text { Plotnikova et al. [139,140] } \\
\text { Kumar et al. [31] } \\
\text { Al-Mailem et al. [111] } \\
\text { Bonfá et al. [144] } \\
\text { Plotnikova et al. [140] } \\
\text { Dastgheib et al. [142] } \\
\text { Al-Mailem et al. [36] } \\
\text { Gao et al. [143] } \\
\text { Erdogmus et al. [132] }\end{array}$ \\
\hline Anthracene & & $\begin{array}{l}\text { EH4 (Haloarcula vallismortis) } \\
\text { Micrococcus sp. Pseudomonas sp. } \\
\text { Alcaligenes sp. } \\
\text { Haloferax spp } \\
\text { Mixed culture (Qphe-SubIV) } \\
\text { Marinobacter sedimentalis } \\
\text { Marinobacter falvimaris } \\
\text { Marinobacter nanhaiticus }\end{array}$ & $\begin{array}{l}\text { Bertrand et al. [227] } \\
\text { Ashok et al. [246] } \\
\text { Bonfá et al. [144] } \\
\text { Dastgheib et al. [142] } \\
\text { Dastgheib et al. [142] } \\
\text { Gao et al. [143] }\end{array}$ \\
\hline
\end{tabular}


Citation: Olajire AA, Essien JP (2014) Aerobic Degradation of Petroleum Components by Microbial Consortia. J Pet Environ Biotechnol 5: 195 doi:10.4172/2157-7463.1000195

Page 13 of 22

\begin{tabular}{|c|c|c|}
\hline Phenanthrene & $\begin{array}{l}\text { EH4 (Haloarcula vallismortis) } \\
\text { Micrococcus sp. Pseudomonas sp. } \\
\text { Alcaligenes sp. } \\
\text { Pseudomonas sp. Arthrobacter sp. Microbial consortium, Shengli Oilfield, China } \\
\text { Haloferax sp } \\
\text { Haloferax sp. Halobacterium } \mathrm{sp} .\end{array}$ & $\begin{array}{l}\text { Bertrand et al. [227] } \\
\text { Ashok et al. [246] } \\
\text { Plotnikova et al. [139,140] } \\
\text { Zhao et al. [141] } \\
\text { Tapilatu et al. [110] } \\
\text { Al-Mailem et al. [111] } \\
\text { Bonfá et al. [144] }\end{array}$ \\
\hline & $\begin{array}{l}\text { Halococcus sp. } \\
\text { Haloferax spp. Mixedculture(Qphe-SubIV) } \\
\text { Marinobacter sedimentalis Marinobacter falvimaris Marinobacter nanhaiticus } \\
\text { Halobacterium piscisalsi, Halorubrum ezzemoulense, Halobacterium salinarium, } \\
\text { Haloarcula hispanica Haloferax } \\
\text { sp. Halorubrum sp. Haloarcula sp. }\end{array}$ & $\begin{array}{l}\text { Dastgheib et al. [142] } \\
\text { Al-Mailem et al. [36] } \\
\text { Gao et al. [143] } \\
\text { Erdogmus et al. [132] }\end{array}$ \\
\hline Acenaphthene & EH4 (Haloarcula vallismortis) & Bertrand et al. [227] \\
\hline Fluorene & $\begin{array}{l}\text { Actinopolyspora sp. DPD } \\
\text { Mixed culture(Qphe-SubIV) }\end{array}$ & $\begin{array}{l}\text { Al-Mueini et al. [107] } \\
\text { Dastgheib et al. [142] }\end{array}$ \\
\hline Pyrene & $\begin{array}{l}\text { Bacillus sp strainDHT } \\
\text { Haloferax spp. Mixedculture(Qphe-SubIV) } \\
\text { Halobacterium piscisalsi, Halorubrum ezzemoulense, Halobacterium salinarium, } \\
\text { Haloarcula hispanica Haloferax } \\
\text { sp. Halorubrum sp. Haloarcula sp. }\end{array}$ & $\begin{array}{l}\text { Kumar et al. [31] } \\
\text { Bonfá et al. [144] } \\
\text { Dastgheib et al. [142] } \\
\text { Erdogmu,s et al. [132] }\end{array}$ \\
\hline Biphenyl & $\begin{array}{l}\text { Rhodococcus sp. Arthrobacter sp. } \\
\text { Haloferax sp. Halobacterium sp. } \\
\text { Halococcus Marinobacter sedimentalis Marinobacter falvimaris }\end{array}$ & $\begin{array}{l}\text { Plotnikova et al. [139,140] } \\
\text { Al-Mailem et al. [111] } \\
\text { Al-Mailem et al. [36] }\end{array}$ \\
\hline
\end{tabular}

Table 5: Microorganisms having degradation potential for polycyclic aromatic hydrocarbons (PAHs).

and Penicllium funiculosum were found to be more predominant in the polluted soil. The highest percentage loss of petroleum hydrocarbon concentration by the mixed cultures of fungi were $90 \%$ with A. niger and A. fumigatus, but the lowest loss of petroleum hydrocarbon calculated in mixed four fungal strains (A. niger, A. fumigatus, $P$. funiculosum and F. solani) to $70 \%$. Vanishree et al. [147] used fungus Penicillium $s p$. for biodegradation of petrol. The efficiency of the fungal strain on the degradation of different concentrations of petrol was studied. The ability of Penicillium sp. to tolerateoil pollutant and grow on them suggest that it can be employed as bioremediation agent and used for restoration of ecosystem contaminated by oil.

Four fungi strains viz. Aspergillus niger, Aspergillus terreus, Rhizopus sp and Penicillium sp were also isolated from soil and tarball samples collected from mangrove forest of Alibaug and Akshi coastal area, Maharashtra, India [148]. These strains were assessed for their degradation capability of petroleum hydrocarbons measuring growth diameter in Potato Dextrose Agar (PDA) solid media for different concentrations of kerosene. Rhizopus sp showed the highest growth diameter in 5\% kerosene and Aspergillus niger showed the highest growth diameter in $20 \%$ kerosene while, penicillium sp showed the lowest growth diameter at all the concentrations of kerosene as compared to other three strains. A mixed culture consisting of penicillium sp, Rhizopus sp and Aspergillus terreus was reported to show highest growth diameter.

Heteroaromatic compounds: Many bacterial species have been reported to decompose dibenzofurans and carbazole, a structural analogue with nitrogen instead of oxygen [149-153]. Guo et al. [151] isolated a stable carbazole-degrading microbial consortium consisting of Chryseobacterium sp. NCY and Achromobacter sp. NCW. The initial reactions of dibenzofuran and carbazole can be classified into angular and lateral dioxygenation, which may be catalyzed by different enzymes. These enzymes were found in Gram-positive and negative bacteria $[138,152,154-156]$. Many bacterial strains have the ability to use carbazole as the sole carbon, nitrogen and energy source [150,157]. Most isolates degraded carbazole by following the so-called angular pathway, in which carbazole is initially attacked at the 1 and 9a positions by carbazole dioxygenase, followed by the spontaneous conversion of the dihydroxylated intermediate to 2'-aminobiphenyl-2,3-diol (Scheme $6)$. An extradiol dioxygenase then attacks the hydroxylated ring at the meta position to give 2-hydroxy-6-(2'-aminophenyl)-6-oxo-2,4hexadienoic acid, which is hydrolysed to produce anthranilic acid and 2-hydroxypenta-2,4-dienoic acid [150,154-157].

Benzothiophene (BT) and its derivatives are the major sulfur heteroaromatic compounds that are commonly found in higher molecular weight fractions of petroleum. However, no bacterial strain has been found to grow on benzothiophenes as the sole carbon source, and all reported biotransformations of benzothiophenes are based on cometabolism. Attacks on the thiophene ring of benzothiophenes lead to the formation of sulfoxides and sulfones, or to ring opening and the formation of 2-mercaptomandelaldehyde and 2-mercaptophenylglyoxalate [158-160]. Catabolism of dibenzothiophene is catalyzed by distinct enzymes in two pathways (Scheme 7). The catabolic branch of initial sulfur oxidation, also called $4 \mathrm{~S}$ pathway, through which rapid desulfurization can be obtained. Consecutive desulfurization is achieved by desulfinase. These monooxygenases require FAD as a co-factor, accompanied by a specific flavin reductase [161]. FAD containing monooxygenases are very common in all biota and catalyze various detoxification 
Citation: Olajire AA, Essien JP (2014) Aerobic Degradation of Petroleum Components by Microbial Consortia. J Pet Environ Biotechnol 5: 195. doi:10.4172/2157-7463.1000195


spontaneous conversion

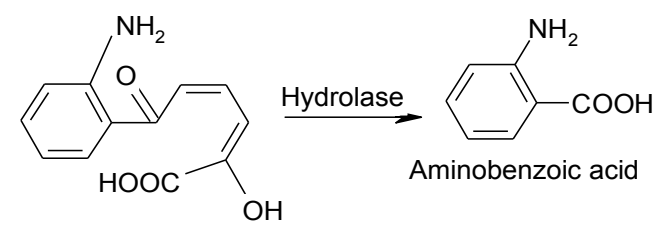

2-Hydroxy-6-oxo-6-(2'-aminobiphenyl)hexa-2,4-dienoic acid

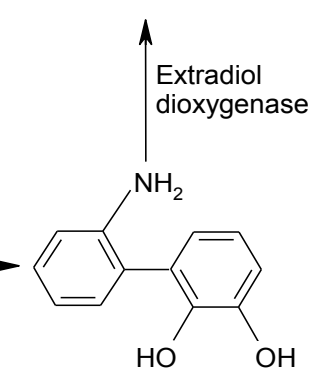

2' Aminobiphenyl-2,3-diol

Scheme 6: Aerobic degradation of carbazole via the angular pathway by various carbazole-utilizing bacteria.

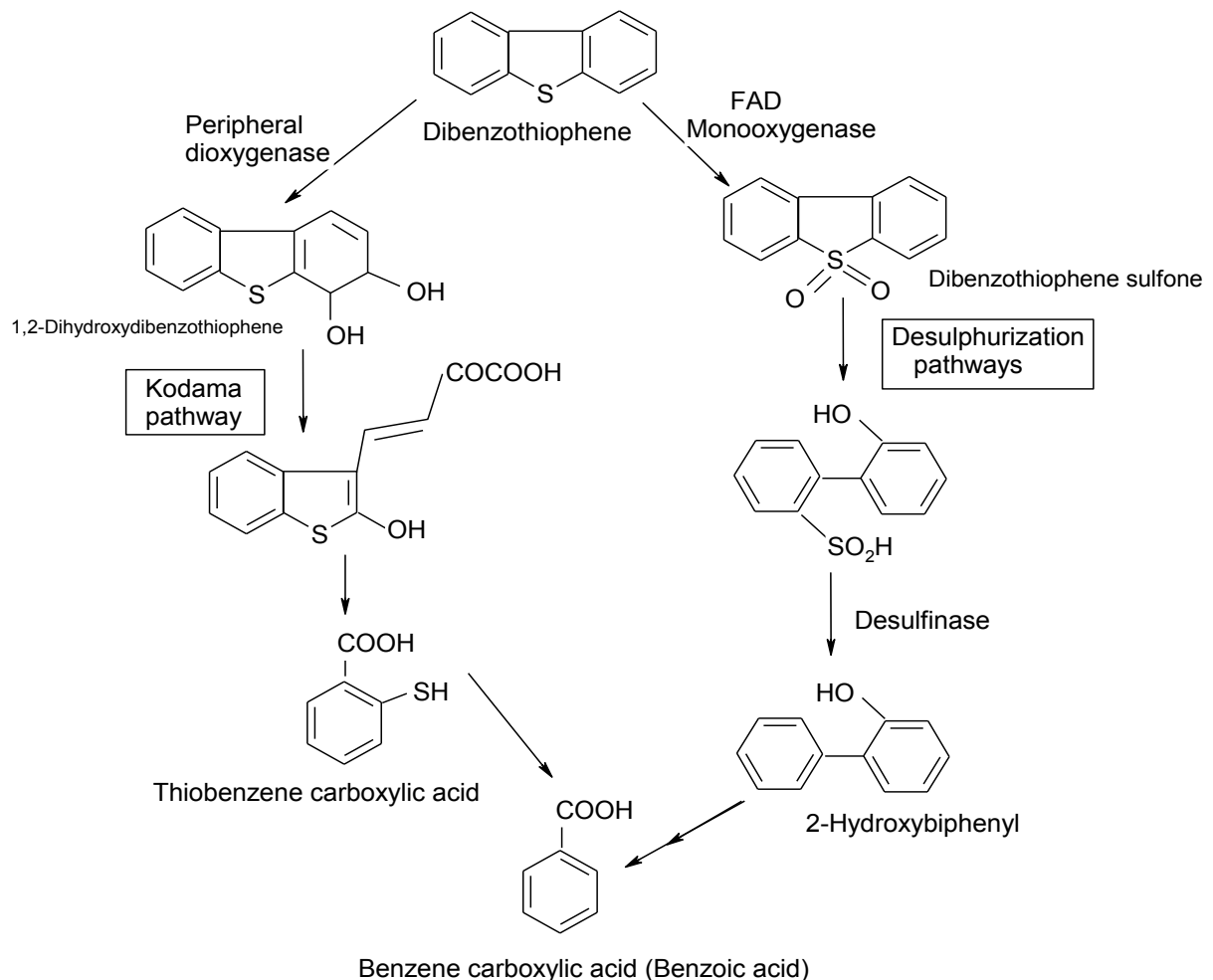

Scheme 7: Bacterial catabolic pathways for the aerobic degradation of dibenzothiophene.

steps. For example, Sutherland et al. [162] reported a FAD containing monooxygenase of high sequence homology with dibenzothiophene desulfurization enzymes. In general, all bacterial species with highdesulfurization activities have the enzymes and broad substrate range $[163,164]$. However, some bacterial species are defective in some components, which results in accumulation of intermediates. In comparison with desulfurization pathway, the enzymes for lateral dioxygenation and consecutive reactions are very different (Kodama pathway, Scheme 7). Many bacterial species have been reported to metabolize dibenzothiophene through Kodama pathway [120,150,165]. Although no detailed research has been done, the structural similarities of the metabolites suggest that common PAH dioxygenase and enzymes in successive steps may be involved in Kodama pathway. 

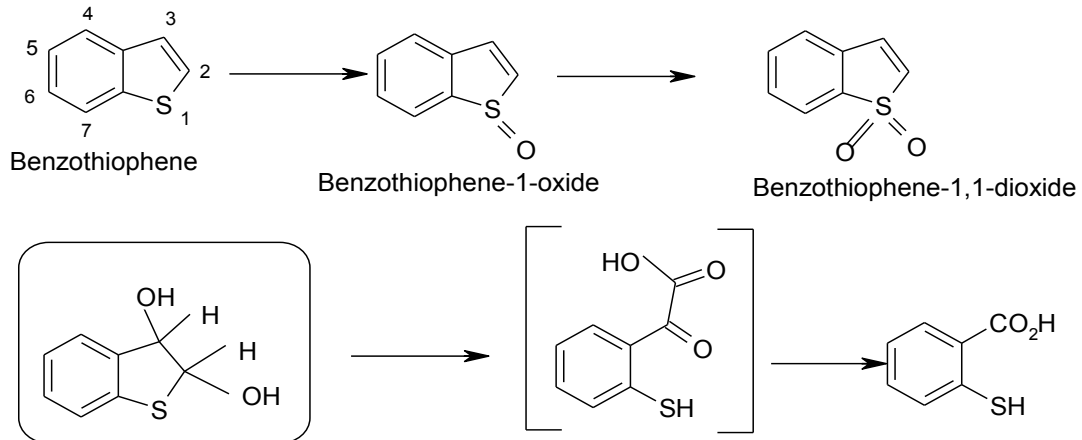

2,3-Dihydroxy-2,3-dihydrobenzothiophene

2-Mercaptophenylglyoxalate

2-Mercaptobenzoic acid


2- and 3-Hydroxybenzothiophene

2-Mercaptomandelaldehyde



Benzothiophene-2,3-dione

Scheme 8: Proposed BT transformation pathways by Sphingomonas sp. XLDN2-5. The compounds in the box were tentatively identified. The compound in brackets was not detected. Dashed arrows indicate transformations that occur during the extraction of products.

Gai et al. [166] investigated the transformation of benzothiophenes (BT) by Sphingomonas sp. XLDN2-5, employing carbazole as an auxiliary substrate. Among the benzothiophenes tested, BT, 2-methylbenzothiophene (2-MBT) and 5-methylbenzothiophene (5MBT) were co-metabolically converted. For 3-methylbenzothiophene, there was complete inhibition of growth on carbazole. The common transformation products for BT, 2-MBT and 5-MBT are the corresponding sulfoxides and sulfones. The authors then concluded that aerobic transformation of benzothiophenes to sulfoxides and sulfones can reduce their toxicity, and facilitate their biodegradation. The proposed metabolic pathways of benzothiophene suggested by the authors are summarized in Scheme 8.

\section{Phylogeny of the oil-degrading microbes}

Oil-degrading microorganisms are ubiquitous in the environment, particularly in the oil-polluted sites. Both fungi and bacteria have been found to be useful in biodegradation process, even though many researches have been on bacteria in the recent times. Although a wide phylogenetic diversity of microorganisms is capable of aerobic degradation of contaminants, Pseudomonas species and closely related organisms have been the most extensively studied owing to their ability to degrade many different contaminants [167]. The oil-degrading populations are widely distributed in the lands and water bodies.

\section{Microbial biodiversity in terrestrial ecosystem}

A conceptualization of the functioning of the ancient terrestrial biosphere necessarily requires a general understanding of modern, analog microbial communities to evaluate their living requirements, diversity, physiology, and environmental impact, and to characterize any potential biosignature that could be used to recognize them in the rocks $[168,169]$. Modern terrestrial microbial communities are found worldwide and in a great variety of local conditions, in surface (solid rock, regolith) and subsurface (caves, groundwater, deep ground) environments. However, it is unclear which one is more productive in terms of biomass [170] and what metabolisms have dominated those systems - and to what extent - over geologic time scales [171]. An understanding of the biology and distribution of modern microbes, which are ubiquitous in today's Earth's biosphere, seems essential for an understanding of their ancient counterparts and their impact on early terrestrial ecosystems. The genetic diversity and biomass distribution in drastically different environments [172-174] depict the ample range of strategies that terrestrial organisms, particularly primary producers, have developed for living on the land. Oxygenic photoautotrophy seems to be a particularly important capability of terrestrial organisms, simply because their energy source (light), reductant power (water), and carbon source $\left(\mathrm{CO}_{2}\right)$ are readily available in these environments. In comparison, other primary producers such as chemolithotrophs are restricted to aqueous environments because they require soluble sources of reductants (e.g., $\mathrm{H}_{2}, \mathrm{Fe}^{2+}, \mathrm{H}_{2} \mathrm{~S}, \mathrm{HS}^{-}$) and exergonic reactions to maintain their metabolism [175]. They are also less energy-efficient than oxygenic photoautotrophs [176-178], and less likely dominant in subaerial environments.

Cyanobacteria have been the only organisms that developed special pigments and enzymatic capabilities for using water as a source of electrons. This process has allowed them to live outside the water in any suitable environment, even where water might be a limiting factor, such as deserts [179]. Oxygenic photosynthesis also contributed to the oxidation of the atmosphere (both by sequestering $\mathrm{CO}_{2}$ and by producing $\mathrm{O}_{2}$ ), a global and ongoing process with profound geochemical, atmospheric, hydrological, and biological implications $[166,180,181]$. Cyanobacteria and other prokaryotes, can also fix gaseous nitrogen, which seems of great advantage for an independence from dissolved $\mathrm{N}$ species, such as $\mathrm{NH}_{4}$ and $\mathrm{NO}_{3}$ [183]. The appearance of cyanobacterial akinetes (for $\mathrm{N}_{2}$ fixation) in the Paleoproterozoic [184] attests to this early adaptation. The limiting nutrients such as P, can be supplied for organisms on land by dust deposition $[185,186]$, which may be an alternative process for replenishment of nutrient loss by runoff and leaching in such environments $[168,187]$; $S$ can also be 
acquired from minerals, aerosols, and as gaseous sources, likely present in the early atmosphere [188]. Thus, the nutritional requirements for oxygenic, photoautotrophic, primary producers seem not to have been a limiting factor for the colonization of the land.

On the basis of the rapid achievement of diversity and distribution of early microbial biota and from microbial successions in modern "barren" lands [189-191], it is expected that heterotrophic organisms were also part of land communities, as they seem to be an inevitable component in this type of consortia. Under this perspective, primitive microbial ecosystems cannot be understood as composed only of autotrophic primary producers, but also a myriad of other microbes finding their niche within such pre-existent microenvironments. For example, actinobacteria in modern cryptogamic covers (CGC) not only degrade large quantities of organic exudates from cyanobacteria, a process which influences the carbon $(\mathrm{C})$ cycle, but they also seem to be structural components of these sedimentary biostructures [192]. The same applies to other bacteria such as Bacteroidetes and Proteobacteria that secrete large quantities of mucopolysaccharides, which aid in gluing soil particles together and may also have a critical role in the hydraulic conductivity of the surface substrate [193].

\section{Microbial biodiversity in aquatic ecosystem}

The emphasis on the organizational level of biodiversity responsible for ecosystem processes is shifting from a species-centered focus to include genotypic diversity. Communities with intermediate species richness show high genotypic diversity while species-poor communities do not [194]. Disturbance of these communities disrupts niche space, resulting in lower genotypic diversity despite the maintenance of species diversity.

Heterotrophic bacteria dwelling in aquatic environments are highly diverse. At coarse level the gram-positive bacteria, the Verrucomicrobiales and the Alpha- and Gamma-Proteobacteria are distributed throughout a range of aquatic habitats including marine and fresh water systems. Some phylogenetic groups appear to be adapted to more narrowly defined niches such as anoxic water and sediments (Delta-Proteobacteria) or aggregates (Bacteroidetes). Betaproteobacteria have been detected throughout freshwater habitats, but these organisms are largely absent from open ocean environments. At narrower level of identification some phylotypes are probably globally distributed as they have been detected in geographically disparate environments. High diversity of heterotrophic bacteria in aquatic environment is explained by high variety of ecological niches occurring and wide spectrum of substrates these organisms utilize.

The abundance of viruses exceeds that of Bacteria and Archaea by approximately 15 -fold in the world ocean. However, because of their extremely small size, viruses represent only approximately $5 \%$ of the prokaryotic biomass because their content of matter is low. Most abundant groups of viruses found in aquatic environments are bacterioand cyanophages. The first metagenomic studies of viral communities have revealed that viral communities contain large amounts of sequences with very low homology to any described sequences available in the literature [195].

\section{Microbial biodiversity in marine ecosystem}

Microbial communities from coastal sediments vary more from one location to another than those from open waters, and have much greater community evenness [196]. Moreover, in sediments, cells are much more concentrated, resulting in a greater likelihood of interactions, which becomes even more prevalent in biofilms where cells are more densely packed. Highly productive photosynthetic microbial mats develop at the water-sediment interface. These multispecies biofilms consist of horizontally stratified layers with extremely steep gradients of light, redox potential, oxygen, sulfur species etc. The exceptionally high microbial diversity within a few microns covers a large range of metabolic groups (oxygenic and anoxygenic phototrophs, sulfate reducers, methanogens etc.) [197]. The communication mechanisms in environments (open water, sediment and biofilms), where small molecules, either diffusing from cell to cell [198], or transported by vesicles [199] or via nanotubes bridging cells [200], elicit intra- and inter-species effects that could be antagonistic or beneficial.

Microbes exhibit all of the types of social behaviour (mutual benefit, selfishness, altruism and spite) seen in multicellular organisms [201]. However, it is often difficult to categorise such behaviour in complex multi-species natural environments. Therefore, a better understanding of crude-oil biodegradation, and thus the capability to more rationally remediate contaminated environments, requires considering the mechanisms of the associations between different hydrocarbondegrading microbes and with non-degrading organisms [15]. Although fungi are considered to be largely terrestrial, they have been found in marine mats [202] and it is known that many can function in saline conditions [203], but in general salt-adapted fungi have received little attention despite a potentially major role in coastal PAH degradation. The ubiquitous co-existence of bacteria and fungi in soil and sediments [204] and their known catabolic cooperation suggests that physical interactions between them may be of importance for PAH degradation.

Marine phototrophs (primarily eukaryotic microalgae and cyanobacteria) contribute half the Earth's primary production and half of the oxygen liberated to the atmosphere [205]. However, they do not exist in isolation, and their phycosphere (loosely defined as the zone around algal cells in which bacteria feed on algal products) constitutes an important habitat that is colonised by an abundant and diverse community of heterotrophic bacteria [206,207].

Bacteria are also found living inside microalgal cells - many with unknown function [145]. The composition of free-living marine microbial communities is frequently very different from those attached to microalgae [208], with certain groups often preferring the attached lifestyle and showing higher levels of activity [194]. Moreover, different species of microalgae host distinct bacterial communities that change with time and environmental conditions [209,210]. However, there is likely to be a large spectrum of bacterial heterotroph-phototroph specificity [211], and certainly many attached bacteria can also live in the absence of a microalgal or cyanobacterial host [212]. While antagonistic interactions occur between marine phototrophs and their attached microbiota $[213,214]$, mutualistic interactions are common. The host supplies carbon and energy sources [215], while the bacteria have been shown to provide iron [216], haem [217], vitamin $B_{12}$ [218] to consume oxygen [219] and provide protection from reactive oxygen species [220]. Symbiotic cyanobacteria supply fixed nitrogen to diatoms [221] and other algae and protests [222], and heterotrophic $\mathrm{N}_{2}$-fixing bacteria may also be important in interactions with microalgae, as evidenced by the abundance of alpha-proteobacterial diazotrophs in seawater size fractions of $>10 \mu \mathrm{m}$ [223].

Marine microbes offer great opportunities for biodiscovery $[224,225]$, yet that potential is yet to be realised. Despite a huge microbial diversity, there is a lack of laboratory cultures of the microbes that are most abundant in the environment that severely limits development of biodiscovery research. Bacteria probably grow as consortia in the sea and reliance on other bacteria for essential nutrients and substrates is 
Citation: Olajire AA, Essien JP (2014) Aerobic Degradation of Petroleum Components by Microbial Consortia. J Pet Environ Biotechnol 5: 195 doi:10.4172/2157-7463.1000195

not possible with standard microbiological approaches. Joint et al. [226] highlighted the advantages of novel technologies, such as encapsulation into gel micro-droplets and development of consortia over standard microbiological approaches for biodiscovery programmes. These technologies, according to the authors resulted in the isolation and culturing of many previously uncultured microbes.

\section{Conclusions}

This review provides the detailed knowledge on the ability of microorganisms capable of degrading hydrocarbons which has accumulated significantly in the past two decades. Studies show that much richer microbial diversity exists in the environment that can efficiently degrade petroleum compounds. Microbial degradation processes aid the elimination of spilled oil from the environment after critical removal of large amounts of the oil by various physical and chemical methods. This is possible because microorganisms have enzymic systems that degrade and utilize different crude oil compounds as source of carbon and energy.

Microbial degradation of oil has been shown to occur by attack on aliphatic or light aromatic fractions of the oil, with high-molecularweight aromatics, resins, and asphaltenes considered to be recalcitrant or exhibiting only very low rates of biodegradation, although some studies have reported their removal at high rates under optimal conditions. The biodegradation of petroleum compounds depends on the specific microbial population present. Further studies should be carried out to identify new bacterial strains that can metabolize a broad range of compounds contained in crude oil, especially the highly persistent components. Also, a better knowledge of the

diversity of catabolic pathways would certainly bring valuable information for the development of robust bioremediation processes.

\section{References}

1. Leahy JG, RR Colwell (1990) Microbial degradation of hydrocarbons in the Environment. Microbiology Reviews 54: 305-315.

2. Atlas RM (1995) Petroleum Biodegradation and Oil Spill Bioremediation, Marine Pollution Bulletin, 31: 178-182.

3. Van Hamme JD, Singh AM, Ward OP (2003) Recent advances in petroleum microbiology Microbiol. Mol. Biol. Rev. 6: 503-549.

4. Muñoz RB, Guieysse, Mattiasson B (2003) Phenanthrene biodegradation by an algal-bacterial consortium in two-phase partitioning bioreactors. Applied Microbiology and Biotechnology 61: 261-267.

5. Radwan SS, Al-Hasan RH, Ali N, Salamah S, Khanafer M (2005) Oil-consuming microbial consortia floating in the Arabian Gulf. International Biodeterioration and Biodegradation 56: 28-33.

6. Chaillan F, Gugger M, Saliot A, Coute A, Oudot J (2006) Role of cyanobacteria in the biodegradation of crude oil by a tropical cyanobacterial mat. Chemosphere 62: 1574-1582.

7. Ubalua AO, Ezeronye OU (2005) Nutrients and selected physico-chemical analysis in the Aba river surface waters, Abia State, Nigeria. Journal of Environmental and Ecology 23: 141-144

8. Tang X, Dang Z, He LY, Lu GN, Tao XQ (2012) Biodegradation of crude oil by an artificial microalgal-bacterial consortium. Open Access Scientific Reports 1: 118.

9. Chang W, Akbari A, Snelgrove J, Frgon D, Ghoshal S (2013) Biodegradation of petroleum hydrocarbons in contaminated clayey soils from a sub-arctic site: the role of aggregate size and microstructure. Chemosphere 91: $1620-1626$.

10. Philip JC, Bamforth SM, Singleton I, Atlas RM (2005) Environmental pollution and restoration: a role for bioremediation, in Bioremediation: Applied Microbial Solutions for Real-World Environmental Cleanup eds R. M. Atlas and J. Philip (Washington,DC:ASM Press), 1-48.
11. Yemashova NA, Murygina VP, Zhukov DV, Zakharyantz AA, Gladchenko MA Appanna $V$ et al. (2007) Biodeterioration of crude oil and oil derived products: a review. Rev.Environ. Sci. Biotechnol. 6: 315-337.

12. Cao B, Nagarajan K, Loh K-C (2009) Biodegradation of aromatic compounds: current status and opportunities for biomolecular approaches. Appl. Microbiol. Biotechnol. 85: 207-228.

13. Harayama S, Kishira H, Kasai Y, Shutsubo K (1999) Petroleum biodegradation in marine environments. Journal of Molecular Microbiology and Biotechnology 1: $63-70$.

14. Head IM, Swannell RP (1999) Bioremediation of petroleum hydrocarbon contaminants in marine habitats. Curr. Opin. Biotechnol. 10: 234-239.

15. Head IM, DM Jones, WFM Röling (2006) Marine microorganisms make a meal of oil. Nature Review Microbiology 4:173-182.

16. McGenity TJ, Folwell BD, McKew BA, Sanni GO (2012) Marine crude-oi biodegradation: a central role for interspecies interactions. Aquatic Biosystems 8:10.

17. Pathak H, Vashistha A, Jain PK, Nagmani A, Jaroli DP, Lowry M (2010) Physcio-chemical properties of petroleum contaminated soil collected from coastal areas of Mumbai, Asian. Journal of Experimental Science 24: 175-178.

18. Olajire AA, Alade AO, Adeniyi AA, Olabemiwo OM (2007) Distribution of polycyclic aromatic hydrocarbons in surface soils and water from the vicinity of Agbabu bitumen field of Southwestern Nigeria. Journal of Environmental Science and Health, Part A 42: 1043-1049.

19. Olajire AA, Olujobade IM, Olabemiwo OM (2008) n-Alkanes distributions in soil and water samples collected near Agbabu bitumen field of Southwestern Nigeria. International Journal of Environmental Studies 65: 769 -779.

20. Zvyagintseva IS, Belyaev SS, Borzenkov IA, Kostrikina NA, Milekhina EI Ivanov MV (1995) Halophilic archaebacteria from the Kalamkass oil field Microbiology 64: 83-87.

21. Diaz MP, Grigson SJW, Peppiatt CJ, Burgess JG (2000) Isolation and characterization of novel hydrocarbon-degrading euryhaline consortia from crude oil and mangrove sediments. Mar. Biotechnol 2: 522-532.

22. Diaz MP, Boyd KG, Grigson SJW, Burgess JG (2002) Biodegradation of crude oil across a wide range of salinities by an extremely halotolerant bacterial consortium MPD-M, immobilized onto polypropylene fibres. Biotechnol. Bioeng. 79: 145-153.

23. Riis V, Kleinsteuber S, Babel W (2003) Influence of high salinities on the degradation of diesel fuel by bacteria consortia. Can. J. Microbiol. 49: 713721.

24. Obuekwe CO, Badrudeen AM, Al-Saleh E, Mulder JL (2005) Growth and hydrocarbon degradation by three desert fungi under conditions of simultaneous temperature and salt stress. Intern. Biodeter. Biodegrad. 56, 197-205.

25. Wang YN, Cai H, Chi CQ, Lu AH, Lin XG, Jian ZF et al. (2007). Halomonas shengliensis sp. nov., a moderately halophilic, denitrifying, crude-oil-utilizing bacterium. Int. J. Syst. Evol. Microbiol. 57: 1222-1226.

26. Mnif S, Chamkha M, Sayadi S (2009) Isolation and characterization of Halomonas sp. strain C2SS100, a hydrocarbon-degrading bacterium under hypersaline conditions. J. Appl. Microbiol. 107, 785-794.

27. Huu NB, Denner EBM, Ha DTC, Wanner G, stan-Lotter H (1999) Marinobacter aquaeolei sp. nov., a halophilic bacterium isolated from a Vietnamese oilproducing well. Int. J. Syst. Bacteriol. 49, 367-375.

28. Kuznetsov VD, Zaitseva TA,Vakulenko LV, Filippova SN (1992) Streptomyces albiaxialis sp.nov.:a new petroleum hydrocarbon-degrading species of thermoand halotolerant Streptomyces. Microbiology 61: 62-67.

29. Zvyagintseva IS, Poglasova MN, Gotoeva MT, Belyaev SS (2001) Effect of the medium salinity on oil degradation by Nocardioform bacteria. Microbiology 70 : 652-656.

30. Borzenkov IA, Milekhina El, Gotoeva MT, Rozanova EP, Belyaev SS (2006) The properties of hydrocarbon-oxidizing bacteria isolated from the oil fields of Tatarstan, Western Siberia, and Vietnam. Microbiology 75: 66-72.

31. Kumar M, Vladimir L, de Sistro Materano A, Ilzins OA (2007) A halotolerant and thermotolerant Bacillus sp.degrades hydrocarbons and produces tension active emulsifying agent. World J. Microbiol. Biotechnol. 23, 211-220.

32. Mnif S, Chamkha M, Labat M, Sayadi S (2011) Simultaneous hydrocarbon biodegradation and biosurfactant production by oil field-selected bacteria. J. Appl. Microbiol. 111: 525-536. 
Citation: Olajire AA, Essien JP (2014) Aerobic Degradation of Petroleum Components by Microbial Consortia. J Pet Environ Biotechnol 5: 195. doi:10.4172/2157-7463.1000195

33. Chamkha M, Mnif S, Sayadi S (2008) Isolation of a thermophilic and halophilic tyrosol-degrading Geobacillus from a Tunisian high-temperature oil field. FEMS Microbiol. Lett. 283: 23-29.

34. Wang YN, Chi CQ, Cai M, Lou ZY, Tang YQ, Zhi XY, et al. (2010)Amycolicicoccus subflavus gen. nov., sp. nov., an actinomycete isolated from a saline soil contaminated by crude oil. Int. J. Syst. Evol. Microbiol. 60: 638-643.

35. Nie Y, Fang H, Li Y, Chi CQ, Tang YQ, Wu XL (2013) The genome of the moderate halophile Amycolicicoccus subflavus DQS3-9A1T reveals four alkane hydroxylation systems and provides some clues on the genetic basis for its adaptation to a petroleum environment. PLoSONE 8: e70986.

36. Al-Mailem DM, Eliyas M, Radwan SS (2013) Oil-bioremediation potential of two hydrocarbonoclastic, diazotrophic Marinobacter strains from hypersaline areas along the Arabian Gulfcoasts. Extremophiles 17: 463-470.

37. Ulrich W (2000) Contaminant soil areas, different countries and contaminant monitoring of contaminants. In: Environmental Process II. Soil Decontamination Biotechnology H. J. Rehm and G. Reed, Eds., 11: 5-42.

38. Atlas R, Bragg J (2009) Bioremediation of marine oil spills: When and when not- the Exxon valdez experience. Microbial Biotechnology 2: 213-221.

39. Fusey P, Oudot J (1984) Relative influence of physical removal and biodegradation in the depuration of petroleum contaminated seashore sediments Marine Pollution Bulletin 15:136-141.

40. Walker JD, Colwell RR, Petrakis L (1976) Biodegradation rates of components of petroleum. Canadian Journal of Microbiology 22: 1209-1213.

41. Atlas RM (1981) Microbial Degradation of petroleum hydrocarbons: an experimental perspective, Microbiol. Rev. 45: 180-209.

42. Gerson DF (1985) The Biophysics of Microbial growth on hydrocarbon: Insoluble substrates. Int. Bioresour. J. 1: 39-53.

43. Bartha R, Bossert I (1984) The treatment and disposal of petroleum wastes, In: petroleum microbiology, R. M. Atlas, Ed., Macmillan, New York, NY, USA.

44. Antai SP, Mgborno E (1993) Pattern of Degradation of Bonny light crude oil by Bacillus Spp. and Pseudomonas Spp isolated from oil spilled site W.A.J. Biol. Appl. Chem. 38: 16-20.

45. Barathi S, Vasudevan N (2001) Utilization of petroleum hydrocarbons by Pseudomonas fluorescens isolated from a petroleum-contaminated soil. Environment International 26: 413-416.

46. Dhaker AK, Jain PK (2011) Sewage pollutants and their bioremediation by using different microorganism. In: Recent Advances in Environmental Biotechnology, Jain P.K., V.K. Gupta and V. Bajpai (Eds.). LAP lambert academic publishing $A G$ and Co. KG, Germany, 189-204.

47. Jain PK, Gupta VK, Pathak H, Lowry M, Jaroli DP (2010) Characterization of $2 \mathrm{~T}$ engine oil degrading indigenous bacteria, collected from high altitude Mussoorie region of India. World Journal of Microbiology and Biotechnology 26: $1419-1426$.

48. Das N, Chandran P (2011) Microbial degradation of petroleum hydrocarbon contaminants: An overview. Biotechnology Research International 1-13.

49. Bajpai VP, Sharma PK, Jain, Gaur RK (2011) Bioremediation of heavy metals - microbial application. In: Recent advances in environmental biotechnology, Jain, P.K., V.K. Gupta, and V. Bajpai. (Eds.). LAP lambert academic publishing $A G$ and Co. KG, Germany, 205-218.

50. Rahman KSM, Rahman TJ, Kourkoutas Y, Petsas I, Marchant R, Banat IM (2003) Enhanced bioremediation of n-alkane in petroleum sludge using bacterial consortium amended with rhamnolipid and micronutrients. Bioresource Technology 90: 159-168.

51. Brooijmans RJW, Pastink MI, Siezen RJ (2009) Hydrocarbon-degrading bacteria: the oil-spill clean-up crew. Microbial Biotechnology 2: 587-594.

52. Yakimov MM, Timmis KN, Golyshin PN (2007) Obligate oil-degrading marine bacteria. Current Opinion in Biotechnology 18: 257-266.

53. Das K, Mukherjee AK (2007) Crude petroleum-oil biodegradation efficiency of Bacillus subtilis and Pseudomonas aeruginosa strains isolated from a petroleum-oil contaminated soil from North-east India. Bioresource Technology 98: $1339-1345$

54. Throne-Holst M, Wentzel A, Ellingsen TE, Kotlar H-K, Zotchev SB (2007) Identification of novel genes involved in long-chain $n$-alkane degradation by Acinetobacter sp. strain DSM 17874. Applied and Environmental Microbiology 73: $3327-3332$
55. Chaillan F, Le Fl'eche A, Bury E et al (2004) Identification and biodegradation potential of tropical aerobic hydrocarbon degrading microorganisms. Research in Microbiology 155: 587-595.

56. Daugulis AJ, McCracken CM (2003) Microbial degradation of high and low molecular weight polyaromatic hydrocarbons in a two-phase partitioning bioreactor by two strains of Sphingomonas sp. Biotechnology Letters 25:14411444.

57. Pathak H, Jain PK, Jaroli DP, Lowry M (2008) Degradation of phenanthrene and anthracene by Pseudomonas strain, isolated from coastal area. Bioremediation Journal 12: 111-116.

58. Igwo-Ezikpe MN, Gbenle OG, Ilori MO, Okpuzor J, Osuntoki AA (2010) High molecular weight polycyclic aromatic hydrocarbons biodegradation by bacteria isolated from contaminated soils in Nigeria. Research Journal of Environmental Sciences 4: 127-137.

59. Jain PK, Lowry M, Gupta VK, Bajpai V, Sharma S, Joshi N, Gaur RK (2010) Enterobacter sp. as an engine oil degrader. Biospectra 5: 115-120.

60. Singh H (2006) Mycoremediation: Fungal Bioremediation, Wiley- Interscience, New York, NY, USA.

61. Adenipekun, Clementina O (2008) Bioremediation of engine-oil polluted soil by Pleurotus tuber-regium Singer, a Nigerian white-rot fungus. African Journal of Biotechnology, 7: 55-58.

62. Adenipekun, Clementina O, Isikhuemhen OS (2008) Bioremediation of engine oil polluted soil by the tropical white rot fungus, Lentinus squarrosulus Mont (Singer), Pakistan Journal of Biological Sciences, 11: 1643-1637.

63. Uzoigwe Cl, Okpokwasili GC (2012) Biodegradation of oil spill dispersants in natural aquatic ecosystem. International Journal of Physical Sciences 7: 5477 5484

64. Ventikos NP, Vergetis EO, Psaraftis HN, Triantafyllou G (2004) A high-leve synthesis of oil spill response equipment and countermeasures. Journal of Hazardous Materials 107: 51-58.

65. Hamzah A, Phan CW, Abu Bakar NF, Wong KK (2013) Biodegradation of crude oil by constructed bacterial consortia and the constituent single bacteria isolated from Malaysia. Bioremediation Journal 17: 1-10.

66. Malik ZA, Ahmed S (2012) Degradation of petroleum hydrocarbons by oil field isolated bacterial consortium. African Journal of Biotechnology 11: 650-658.

67. Bogusławska-Was E, Da,browski W (2001) The seasonal variability of yeasts and yeast-like organisms in water and bottom sediment of the Szczecin lagoon. International Journal of Hygiene and Environmental Health 203: 451-458.

68. Kumari M, Abraham J (2011) Biodegradation of diesel oil using yeast Rhodosporidium toruloides. Research Journal of Environmental Toxicology 5: 369-377.

69. Hidayat A, Tachibana S (2012) Biodegradation of aliphatic hydrocarbon in three types of crude oil by Fusarium sp. F092 under stress with artificial sea water. Journal of Environmental Science and Technology 5: 64-73.

70. Walker JD, Colwell RR, Vaituzis Z, Meyer SA (1975) Petroleum degrading achlorophyllous alga Prototheca zopfii, Nature 254: 423-424.

71. Cerniglia CE, Gibson DT, Van Baalen C (1980) Oxidation of naphthalene by cyanobacteria and microalgae. Journal of General Microbiology 116: 495-500.

72. Gesinde AF, Agbo EB, Agho MO, Dike EFC (2008) Bioremediation of some Nigerian and Arabian crude oils by fungal isolates. Int. J. Pure and Appl. Sci. 2: 37-44.

73. Obire O, Anyanwu EC (2009) Impact of various concentrations of crude oil on fungal populations of soil. Int J Environ Sci Technol 6: 211-218.

74. Adekunle AA, Adebambo OA (2007) Petroleum hydrocarbon utilization by fungi isolated from Detarium senegalense (J. F Gmelin) seeds. Journal of American Science 3: 69-76.

75. Hadibarata T, Tachibana S (2009) Microbial Degradation of n-Eicosane by Filamentous Fungi. Interdisciplinary Studies on Environmental Chemistry, Environmental Research in Asia.

76. Hadibarata T, Tachibana S (2009) Microbial Degradation of Crude Oil by Fungi Pre-Grown on Wood Meal. Interdisciplinary Studies on Environmental Chemistry, Environmental Research in Asia

77. Adekunle AA, Uaboni-Egbenni PO, Ajayi T (2004) Biodegradation of petroleum products by Saccharomyces cerevisae isolated from the Lagos, lagoon 17: 8394. 
Citation: Olajire AA, Essien JP (2014) Aerobic Degradation of Petroleum Components by Microbial Consortia. J Pet Environ Biotechnol 5: 195. doi:10.4172/2157-7463.1000195

Page 19 of 22

78. Atagana HI, Haynes RJ, Wallis FW (2006) Fungal bioremediation of creosotecontaminated soil: A laboratory scale bioremediation study using indigenous soil fungi. Water Air Soil Pollut 172: 201-219.

79. Husaini A, Roslan HA, Hii KSY, Ang CH (2008) Biodegradation of aliphatic hydrocarbon by indigenous fungi isolated from used motor oil contaminated sites. World J Microbiol Biotechnol 24: 2789-2797.

80. Romero MC, Urrutia MI, Reinoso HE, Kiernan MM (2010) Benzo[a]pyrene degradation by soil filamentous fungi. J. yeast Fungal Res 1: 025-029.

81. Saraswathy A, Hallberg R (2002) Degradation of pyrene by indigenous fungi from a former gasworks site. FEMS Microbiol Lett 210: 227-232.

82. Batelle CD (2000) Mushrooms: Higher Macrofungi to clean up the environment. Environmental Issues, Fall 2000.

83. Ojo OA (2005) Petroleum-hydrocarbon utilization by native bacterial population from a waste water canal southwest Nigeria. Afr J Biotechnol 5: 333-337.

84. Kostka JE, Prakash O, Overholt WA, Green SJ, Freyer G, Canion A, Delgardio J, Norton N, Hazen TC, Huettel M (2011) Hydrocarbon-degrading bacteria and the bacterial community response in Gulf of Mexico beach sands impacted by the deepwater horizon oil spill. Applied and Environmental Microbiology 77 : 7962-7974.

85. Teramoto M, Suzuki M, Okazaki F, Hatmanti A, Harayama S (2009) Oceanobacter-related bacteria are important for the degradation of petroleum Aliphatic hydrocarbons in the tropical marine environment. Microbiology 155: 3362-3370.

86. McKew BA, Coulon F, Yakimov MM, Denaro R, Genovese M, Smith CJ, Osborn AM, Timmis KN, McGenity TJ (2007) Efficacy of intervention strategies for bioremediation of crude oil in marine systems and effects on indigenous hydrocarbonoclastic bacteria. Environmental Microbiology 9: 1562-1571.

87. Coulon F, McKew BA, Osborn AM, McGenity TJ, Timmis KN (2007) Effects of temperature and biostimulation on oil-degrading microbial communities in temperate estuarine waters. Environmental Microbiology 9: 177-186.

88. Yakimov MM, Golyshin PN, Lang S, Moore ERB, Abraham WR, Lunsdor H, Timmis KN (1998) Alcanivorax borkumensis gen. nov., sp. nov., a new, hydrocarbon-degrading and surfactant-producing marine bacterium. International Journal of Systemic Bacteriology 48: 339-348.

89. Schneiker SVA, dos Santos PM, Bartels D, Bekel T, Brecht M, Buhrmester J Chernikova TN et al. (2006) Genome sequence of the ubiquitous hydrocarbondegrading marine bacterium Alcanivorax borkumensis. Nature Biotechnology 24: 997-1004.

90. Sabirova JS, Ferrer M, Regenhardt D, Timmis KN, Golyshin PN (2006) Proteomic insights into metabolic adaptations in Alcanivorax borkumensis Induced by alkane utilization. Journal of Bacteriology 188: 3763-3773.

91. Sabirova JS, Chernikova TN, Timmis KN, Golyshin PN (2008) Niche-specificity factors of a marine oil-degrading bacterium Alcanivorax borkumensis SK2. FEMS Microbiology Letter 85: 89-96.

92. Ron E, Rosenberg E (2010) Acinetobacter and alkanindiges. In: Handbook of hydrocarbon and lipid microbiology. Edited by Timmis KN, McGenity TJ, Meer JR, Lorenzo V. Springer, Berlin Heidelberg; 1800-1803.

93. Rojo F (2009) Degradation of alkanes by bacteria. Environmental Microbiology $11: 2477-2490$

94. Adebusoye SA, Ilori MO, Amund OO, Teniola OD, Olatope SO (2007) Microbial degradation of petroleum hydrocarbons in a polluted tropical stream. World Journal of Microbiology and Biotechnology 23: 1149-1159.

95. Fritsche W, Hofrichter M (2000) Aerobic degradation by microorganisms, In Environmental Processes- Soil Decontamination, J Klein, Ed., Wiley-VCH, Weinheim, Germany.

96. Jan B, Beilen V, Neuenschwunder M, Suits THM, Roth C, Balada SB Witholt B (2003) Rubredoxins involved in alkane Degradation. The Journal of Bacteriology 184: 1722-1732.

97. 97. van Beilen JB, Funhoff EG (2007) Alkane hydroxylases involved in microbial alkane degradation. Applied Microbiology and Biotechnology 74: 13-21.

98. Obayori OS, Ilori MO, Adebusoye SA, Oyetibo GO, Omotayo AE, Amund OO (2009) Degradation of hydrocarbons and biosurfactant production by Pseudomonas sp. strain LP1. World Journal of Microbiology and Biotechnology 25: $1615-1623$.
99. Shanklin J, Achim C, Schmidt H, Fox BG, Munck E (1997) Mossbauer studies of alkane omega-hydroxylase: evidence for a diiron cluster in an integralmembrane Enzyme. Proceedings of National Academic of Sciences USA 94 2981-2986.

100. Whyte LG, Hawari J, Zhou E, Bourbonniere L, Inniss WE, Greer CW (1998) Biodegradation of variable-chain-length alkanes at low temperatures by a Psychrotrophic rhodococcus sp. Applied and Environmental Microbiology 64 2578-2584.

101. McDonald IR, Miguez CB, Rogge G, Bourque D, Wendlandt KD, Groleau D, Murrell JC (2006) Diversity of soluble methane monooxygenase-containing methanotrophs isolated from polluted environments. FEMS Microbiology Letters 255: 225-232.

102. Maeng JH, Sakai Y, Tani Y, Kato N (1996) Isolation and characterization of a novel oxygenase that catalyzes the first step of $n$-alkane oxidation in Acinetobacter sp. strain M-1. Journal of Bacteriology 178: 3695- 3700.

103. Hommel RK (1990) Formation and phylogenetic role of biosurfactants. Journal of Applied Microbiology 89: 158-191.

104. lida T, Sumita T, Ohta A, Takagi M (2000) The cytochrome P450ALK multigene family of an n-alkane-assimilating yeast, Yarrowia lipolytica: Cloning and characterization of genes coding for new CYP52 family members. Yeast 16: 1077-1087.

105. Scheller U, Zimmer T, Becher D, Schauer F, Schunck WH (1998) Oxygenation cascade in conversion of $n$-alkanes to $\alpha, \omega$-dioic acids catalyzed by cytochrome P450 52A3. Journal of Biological Chemistry 273: 32528-32534.

106. Nakajima K, Sato A, Takahara Y, lida T (1985) Microbial oxidation of isoprenoid alkanes, phytane, norpristane and farnesane. Agricultural and Biological Chemistry 49:1993-2002.

107. Al-Mueini R, Al-Dalali M, Al-Amri IS, Patzelt H (2007) Hydrocarbon degradation at high salinity by a novel extremely halophilic actinomycete. Environ. Chem. 4: 5-7.

108. Sass AM, McKew BA, Sass H, Fichtel J, Timmis KN, McGenity TJ (2008) Diversity of Bacillus -like organisms isolated from deep-sea hypersaline anoxic sediments. Saline Syst. 4: 8.

109. Dastgheib SMM, Amoozegar MA, Khajeh K, Ventosa A (2011) A halotolerant Alcanivorax sp. strain with potential application in saline soil remediation. Appl. Microbiol. Biotechnol. 90: 305-312.

110. Tapilatu YH, Grossi V, Acquaviva M, Militon C, Bertrand J-C, Cuny P (2010) Isolation of hydrocarbon-degrading extremely halophilic archaea from an uncontaminated hypersaline pond (Camargue, France). Extremophiles 14 225-231.

111. Al-Mailem DM, Sorkhoh NA, Al-Awadhi H, Eliyas M, Radwan SS (2010) Biodegradation of crude oil and pure hydrocarbons by extreme halophilic archaea from hypersaline coasts of the Arabian Gulf. Extremophiles 14: 321 328.

112. van Beilen JB, Funhoff EG, Van Loon A, Just A, Kaysser L, Bouza $M$ Holtackers R, Röthlisberger M, Li Z, Witholt B (2006) Cytochrome P450 alkane hydroxylases of the CYP153 family are common in alkane-degrading eubacteria lacking integral membrane alkane hydroxylases. Applied and Environmental Microbiology 72: 59-65.

113. Panke S, S'anchez-Romero JM, De Lorenzo V (1998) Engineering of quasinatural Pseudomonas putida strains toluene metabolism through an orthocleavage degradation pathway. Applied and Environmental Microbiology 64 748-751.

114. Suyama A, Iwakiri R, Kimura N, Nishi A, Nakamura K, Furukawa K (1996) Engineering hybrid pseudomonads capable of utilizing a wide range of aromatic hydrocarbons and of efficient degradation of trichloroethylene. Journal of Bacteriology 178: 4039-4046.

115. Johnson GR, Olsen RH (1997) Multiple pathways for toluene degradation in Burkholderia sp. strain JS150. Applied and Environmental Microbiology 63 : 4047- 4052.

116. Atlas RM, Bartha R (1998) Fundamentals and applications. In: Microbial ecology. $4^{\text {th }}$ edition. Benjamin/Cummings publishing company, Inc. California, USA, 523- 530.

117. Cebron A, M-P Norini, Beguiristain T, Leyval C (2008) Real-Time PCR quantification of $\mathrm{PAH}$ ring hydroxylating dioxygenase (PAH-RHDa) genes from Gram positive and Gram negative bacteria in soil and sediment samples. Journal of Microbiological Methods 73:148-159. 
Citation: Olajire AA, Essien JP (2014) Aerobic Degradation of Petroleum Components by Microbial Consortia. J Pet Environ Biotechnol 5: 195 doi:10.4172/2157-7463.1000195

Page 20 of 22

118. Keum Y-S, Seo J-S, Li QX, Kim J-H (2008) Comparative metabolomic analysis of Sinorhizobium sp. C4 during the degradation of phenanthrene. Applied Microbiology and Biotechnology 80: 863-872.

119. Rentz JA, Alvarez PJJ, Schnoor JL (2008) Benzo[a]pyrene degradation by Sphingomonas yanoikuyae JAR02. Environmental Pollution 151: 669-677.

120.Seo J -S, Keum Y-S, Li QX (2009) Bacterial degradation of aromatic compounds. International Journal Environmental Research and Public Health 6: 278-309.

121. Woolard CR, Irvine RL (1995) Treatment of hypersaline wastewater in the sequencing batch reactor. Water Res. 29, 1159-1168.

122. Alva V, Peyton BM (2003) Phenol and catechol biodegradation by the haloalkaliphile Halomonascampisalis: influence of $\mathrm{pH}$ and salinity. Environ. Sci. Technol. 37: 4397-4402.

123. Garcia MT, Gallego V, Ventosa A, Mellado E (2005) Thalassobacillus devoransgen. nov., sp. nov., a moderately halophilic, phenol-degrading, Grampositive bacterium. Int. J. Syst. Evol. Microbiol. 55, 1789-1795.

124. Bonfá MRL, Grossman MJ, Piubeli F, Mellado E, Durrant LR (2013) Phenol degradation by halophilic bacteria isolated from hypersaline environments. Biodegradation 24: 699-709.

125. Rosenberg $\mathrm{A}(1983)$ Pseudomonas halodurans sp. nov., a halotolerant bacterium. Arch. Microbiol. 136, 117-123.

126. Garcia MT, Mellado E, Ostos JC, Ventosa A (2004) Halomonas organivorans sp. nov., a moderate halophile able to degrade aromatic compounds. Int. J. Syst. Evol. Microbiol. 54: 1723-1728.

127. Garcia MT, Ventosa A, Mellado E (2005) Catabolic versatility of aromatic compound-degrading halophilic bacteria. FEMS Microbiol. Ecol. 54: 97-109.

128. Abdelkafi S, Labat M, Casalot L, Chamkha M, Sayadi S (2006) Isolation and characterization of Halomonas sp. strain IMPC, a $p$ - coumaric acidmetabolizing bacterium that decarboxylates other cinnamic acids under hypersaline conditions. FEMS Microbiol. Lett. 255: 108-114.

129. Oie CS, Albaugh CE, Peyton BM (2007) Benzoate and salicylate degradation by Halomonascampisalis, an alkaliphilic and moderately halophilic microorganism. Water Res. 41: 1235-1242.

130. Kim D, Kim SW, Choi KY, Lee JS, Kim E (2008) Molecular cloning and functional characterization of the genes encoding benzoate and $p$-hydroxybenzoate degradation by the halophilic Chromohalobacter sp. strain HS-2. FEMS Microbiol. Lett. 280: 235-241.

131. Cuadros-Orellana S, Pohlschroderb M, Grossmanc MJ, Durrant LR (2012) Biodegradation of aromatic compounds by a halophilic archaeon isolated from the Dead Sea. Chem. Eng. Trans. 27: 13-18.

132. Erdogmu s SF, Mutlu B, Korcan SE, Guven K, Konuk M (2013) Aromatic hydrocarbon degradation by halophilic archaea isolated from Çamalti Saltern, Turkey. Water Air Soil Pollut. 224: 1449.

133. Neff J, Lee K, De Blois EM (2011) Produced water: overview of composition, fates, and effects, In: Produced Water: Environmental Risks and Advances in Mitigation Technologies eds. K. Lee and J. Neff (NewYork, NY: Springer Science+BusinessMedia, LLC), 3-54.

134. Nicholson CA, Fathepure BZ (2004) Biodegradation of benzene by halophilic and halotolerant bacteria under aerobic conditions. Appl. Environ. Microbiol. 70: $1222-1225$.

135. Nicholson CA, Fathepure BZ (2005) Aerobic biodegradation of benzene and toluene under hypersaline conditions at the Great Salt Plains, Oklahoma. FEMS Microbiol. Lett. 245: 257-262.

136. Hassan HA, Rizk NMH, Hefnawy MA, Awad AM (2012) Isolation and characterization of halophilic aromatic and chloroaromatic degrader from Wadi El-Natrun Soda lakes. Life Sci J 9: 1565-1570.

137. Al-Turki Al (2009) Microbial polycyclic aromatic hydrocarbons degradation in soil. Research Journal of Environmental Toxicology 3: 1-8.

138. Harayama S, Kok M, Neidle EL (1992) Functional and evolutionary relationships among diverse oxygenases. Annual Review of Microbiology 46: 565- 601.

139. Plotnikova EG, Alyntseva OV, Kosheleva IA, Puntus IF, Filonov AE, GavrishElu et al. (2001). Bacterial degraders of polycyclic aromatic hydrocarbons isolated from salt-contaminated soils and bottom sediments in salt mining areas. Microbiology 70: 51-58.
140. Plotnikova EG, Yastrebova OV, Anan'ina LN, Dorofeeva LV, Lysanskaya V Ya, Demakov VA (2011) Halotolerant bacteria of the genus Arthrobacter degrading polycyclic aromatic hydrocarbons. Russian J. Ecol. 42: 502-509.

141.Zhao B, Wang H, Mao X, Li R (2009) Biodegradation of phenanthrene by a halophilic bacterial consortium under aerobic conditions. Curr. Microbiol. 58: 205-210.

142. Dastgheib SMM, Amoozegar MA, Khajeh K, Shavandi M, Ventosa A (2012) Biodegradation of polycyclic aromatic hydrocarbons by a halophilic microbial consortium. Appl. Microbiol. Biotechnol. 95: 789-798.

143. Gao W, Cui Z, Li Q, Xu G, Jia X, Zheng L (2013) Marinobacternan-haiticus sp. nov., polycyclic aromatic hydrocarbon-degrading bacterium isolated from the sediment of the South China Sea. Antonie Van Leeuwenhoek 103: 485-491.

144. Bonfá MRL,Grossman MJ, Mellado E, Durrant LR (2011) Biodegradation of aromatic hydrocarbons by Haloarchaea and their use for the reduction of the chemical oxygen demand of hypersaline petroleum produced water. Chemosphere 84: 1671-1676.

145. Armbrust EV (2009) The life of diatoms in the world's oceans. Nature 459: 185-192.

146. Flayyih I, Al-Jawhari H (2014) Ability of some soil fungi in biodegradation of petroleum hydrocarbon, Journal of Applied \& Environmental Microbiology 2: 46-52.

147. Vanishree M, Thatheyus AJ and Ramya D (2014). Biodegradation of petrol using the fungus Penicillium sp. Science International, 2: 26-31.

148. LotfinasabasI S, Gunale VR, and Rajurkar NS (2012) Assessment of petroleum hydrocarbon degradation from soil and tarball by fungi, Bioscience Discovery 3: $186-192$.

149. Becher D, Specht M, Hammer E, Francke W, Schauer F (2000) Cometabolic degradation of dibenzofuran by biphenyl-cultivated Ralstonia sp. strain SBUG 290. Applied and Environmental Microbiology 66: 4528-4531.

150. Gai Z, Yu B, Li L, Wang Y, Ma C, Feng J, Deng Z, Xu P (2007) Cometabolic degradation of dibenzofuran and dibenzothiophene by a newly isolated carbazole- degrading Sphingomonas sp. strain. Applied and Environmental Microbiology 73: 2832-2838.

151. Guo W, Li D, Tao Y, Gao P, Hu J (2008) Isolation and description of a stable carbazole-degrading microbial consortium consisting of Chryseobacterium sp. NCY and Achromobacter sp. NCW. Current Microbiology 57: 251-257.

152. Nam JW, Nojiri H, Noguchi H, Uchimura H, Yoshida T, Habe H, Yamane H, Omor T (2002) Purification and Characterization of Carbazole 1,9a-dioxygenase, three-component dioxygenase system of Pseudomonas resinovorans strain CA10. Applied and Environmental Microbiology 68:5882-5890.

153. Seo J-S, Y-S Keum, Cho IK, Li QX (2006) Degradation of dibenzothiophene and carbazole by Arthrobacter sp. P1-1. International Biodeterioration and Biodegradation 58:36-43.

154. Habe H, Chung JS, Lee JH, Kasuga K, Yoshida T, Nojiri H, Omori T (2001) Degradation of chlorinated dibenzofurans and dibenzo-p-dioxins by two types of bacteria having angular dioxygenases with different Features. Applied and Environmental Microbiology 67: 3610-3617.

155. Inoue K, Habe H, Yamane H, Nojiri H (2006) Characterization of novel carbazole catabolism genes from gram-positive carbazole degrader Nocardioides aromaticivorans IC177. Applied and Environmental Microbiology 72: 3321-3329.

156. Nam IH, Kim YM, Schmidt S, Chang YS (2006) Biotransformation of 1,2,3-triand 1,2,3,4,7,8-hexachlorodibenzo-p- dioxin by Sphingomonas wittichii strain RW1. Applied and Environmental Microbiology 72: 112-116.

157. Nojiri H, Nam JW, Kosaka M, Morii KI, Takemura T, Furihata K, Yamane H, Omori $\mathrm{T}$ (1999) Diverse oxygenations catalyzed by carbazole 1,9a-dioxygenase from Pseudomonas sp. strain CA10. J Bacteriol 181: 3105-3113.

158. Saftic' S, Fedorak PM, Andersson JT (1992) Diones, sulfoxides, and sulfones from the aerobic cometabolism of methylbenzothiophenes by Pseudomonas strain BT1. Environ Sci Technol 26: 1759-1764.

159. Eaton RW, Nitterauer JD (1994) Biotransformation of benzothiophene by isopropylbenzene-degrading bacteria. J Bacteriol 176: 3992-4002.

160. Gilbert SC, Morton J, Buchanan S, Oldfield C, McRoberts A (1998) Isolation of a unique benzothiophene-desulphurizing bacterium, Gordona sp. strain 213E (NCIMB 40816), and characterization of the desulphurization pathway. Microbiology 144: 2545-2553. 
Citation: Olajire AA, Essien JP (2014) Aerobic Degradation of Petroleum Components by Microbial Consortia. J Pet Environ Biotechnol 5: 195 doi:10.4172/2157-7463.1000195

Page 21 of 22

161. Matsubara T, Ohshiro T, Nishina Y, Izumi Y (2001) Purification, characterization, and overexpression of flavin reductase involved in dibenzothiophene desulfurization by Rhodococcus erythropolis D-1. Applied and Environmental Microbiology 67: 1179-1184.

162. Sutherland TD, Horne I, Russell RJ, Oakeshott JG (2002) Gene cloning and molecular characterization of a two-enzyme system catalyzing the oxidative detoxification of $ß$-endosulfan. Applied and Environmental Microbiology 68 : 6237-6245.

163. Folsom BR, Schieche DR, DiGrazia PM, Werner J, Palmer S (1999) Microbia desulfurization of alkylated dibenzothiophenes from a hydrodesulfurized middle distillate by Rhodococcus erythropolis 1-19. Applied and Environmental Microbiology 65: 4967-4972.

164. Kirimura KT, Furuya RS, Ishii Y, Kino K, Usami S (2002) Biodesulfurization of naphthothiophene and benzothiophene through selective cleavage of carbonsulfur bonds by Rhodococcus sp. strain WU-K2R. Applied and Environmental Microbiology 68: 3867-3872.

165. Resnick, S.M. and D.T. Gibson (1996) Regio- and stereospecific oxidation of fluorene, dibenzofuran, and dibenzothiophene by naphthalene dioxygenase from Pseudomonas sp. strain NCIB 9816-4. Applied and Environmental Microbiology 62: 4073-4080.

166. Gai Z, Yu B, Wang X, Deng Z, Xu P (2008) Microbial transformation of benzothiophenes, with carbazole as the auxiliary substrate, by Sphingomonas sp. strain XLDN2-5. Microbiology. 154: 3804-3812.

167. Wackett LP (2003) Pseudomonas putida-A versatile biocatalyst. Nature Biotechnology 21: 136-138.

168. Beraldi-Campesi H (2013) Early life on land and the first terrestrial ecosystems. Ecological Processes 2: 1-17.

169. Beraldi-Campesi H, Farmer JD, Garica-Pichel (2011) Evidence for mesoproterozoic life on land and its modern counterpart in arid soils. Proceedings of the GSA Annual Meeting, Minneapolis.

170. Pace N (1997) A molecular view of microbial diversity and the biosphere. Science 276: 734-740.

171. Sleep NH, Bird DK (2007) Niches of the pre-photosynthetic biosphere and geologic preservation of earth's earliest ecology. Geobiology 5: 101-117.

172. Garcia-Pichel F, Belnap J, Neuer S, Schanz F (2003) Estimates of global cyanobacterial biomass and its distribution. Algological Studies 109: 213-227.

173.Lozupone CA, Knight R (2007) Global patterns in bacterial diversity. Proceedings of National Academy of Sciences, USA 104: 11436-11440.

174. Nemergut DR, Costello EK, Hamady M, Lozupone C, Jiang L, Schmidt SK Fierer N, Townsend AR, Cleveland CC, Stanish L, Knight R (2011) Global patterns in the biogeography of bacterial taxa. Environmental Microbiology 13 135-144.

175. White D (2000) The physiology and biochemistry of prokaryotes, 2 nd edn Oxford University Press, Oxford.

176. DesMarais DJ (2000) When did photosynthesis emerge on earth? Science 289: 1703-1705.

177. Madigan MJ, Martinko, Parker J (2003) Brock: biology of microorganisms, $10^{\text {th }}$ edn. Pearson-Prentice Hall, Upper Saddle River, NJ, USA.

178. Konhauser K (2007) Introduction to Geomicrobiology. Blackwell, Oxford.

179. Potts M, Friedmann El (1981) Effects of water stress on cryptoendolithic cyanobacteria from hot desert rocks. Archives of Microbiology 130: 267-271.

180. Rosing MT, Bird DK, Sleep NH, Glassley W, Albarede F (2006) The rise of continents-An essay on the geologic consequences of photosynthesis. Palaeogeography Palaeoclimateology Palaeoecology 232 : 99-113.

181. Och LM, Shields-Zhou GA (2012) The neoproterozoic oxygenation event environmental perturbations and biogeochemical cycling. Earth Science Reviews 110: 26-57.

182. Pufahl PK, Hiatt EE (2012) Oxygenation of the earth's atmosphere-ocean system: A review of physical and chemical sedimentologic responses. Marine and Petroleum Geology 32: 1-20.

183. Glass JB, Wolfe-Simon F, Anbar AD (2009) Coevolution of metal availability and nitrogen assimilation in cyanobacteria and algae. Geobiology 7: 100-123.
184. Tomitani A, Knoll AH, Cavanaugh CM, Ohno T (2006) The evolutionary diversification of cyanobacteria: molecular-phylogenetic and paleontological perspectives. Proceeding of National Academy of Sciences, USA 103: 54425447.

185. Kennedy MJ, Chadwick OA, Vitousek PM, Derry LA, Hendricks DM (1998) Changing sources of base cations during ecosystem development, Hawaiian Islands. Geology 26: 1015-1018.

186. Reynolds R, Belnap J, Reheis M, Lamothe P, Luiszer F (2001) Aeolian dust in Colorado Plateau soils: nutrient inputs and recent change in source. Proceeding of National Academy of Sciences, USA 98: 7123-7127.

187. Beraldi-Campesi H, Hartnett HE, Anbar A, Gordon GW, Garcia-Pichel F (2009) Effect of biological soil crusts on soil elemental concentrations: implications for biogeochemistry and as traceable biosignatures of ancient life on land. Geobiology 7: 348-359.

188. Holland HD (1984) The chemical evolution of the atmosphere and oceans Princeton University Press, Princeton.

189. Sigler WV, Crivii S, Zeyer J (2002) Bacterial succession in glacial forefield soils characterized by community structure, activity and opportunistic growth dynamics. Microbial Ecology 44: 306-316.

190.Schmidt SK, Reed SC, Nemergut DR, Stuart-Grandy A, Cleveland CC et a (2008) The earliest stages of ecosystem succession in high-elevation (5000 metres above sea level), recently deglaciated soils. Proceedings of Biological Sciences 275: 2793-2802.

191. Fierer N, Nemergut D, Knight D, Craine JM (2010) Changes through time: integrating microorganisms into the study of succession. Research in Microbiology 161: 635-642.

192. Reddy SG, Garcia-Pichel F (2006) The community and phylogenetic diversity of biological soil crusts in the Colorado Plateau studied by molecular fingerprinting and intensive cultivation. Microbial Ecology 52: 345-357.

193. Rossi F, Potrafka RM, Garcia-Pichel F, De Philippis R (2012) The role of the exopolysaccharides in enhancing hydraulic conductivity of biological soil crusts. Soil Biology and Biochemistry 46: 33-40.

194. Parnell JJ, Crowl TA, Weimer BC, Pfrender ME (2009) Biodiversity in microbial communities: system scale patterns and mechanisms. Molecular Ecology 18 $1455-1462$

195. Suttle CA (2007) Marine viruses - major players in the global ecosystem. Nature Reviews Microbiology 5: 801-812.

196.Zinger L, Amaral-Zettler LA, Fuhrman JA, Horner-Devine MC, Huse SM Welch DB, Martiny JB, Sogin M, Boetius A, Ramette A (2011) Global patterns of bacterial beta-diversity in seafloor and seawater ecosystems. PLoS One 6: $245-270$.

197.Duran R, Goñi-Urriza MS (2010) Impact of pollution on microbial mats. In Handbook of Hydrocarbon and Lipid Microbiology. Edited by Timmis KN McGenity TJ, Meer JR, Lorenzo V. Springer, Berlin Heidelberg, 2339-2348.

198. Shank EA, Kolter R (2009) New developments in microbial interspecies signalling. Current Opinion on Microbiology 12:205-214.

199. Mashburn-Warren LM, Whiteley M (2006) Special delivery: vesicle trafficking in prokaryotes. Molecular Microbiology 61: 839-846.

200.Dubey GP, Ben-Yehuda S (2011) Intercellular nanotubes mediate bacterial communication. Cell 144: 590-600.

201.Diggle SP (2010) Microbial communication and virulence: lessons from evolutionary theory. Microbiology 156: 3503-3512.

202. Allen MA, Goh F, Burns BP, Neilan BA (2009) Bacterial, archaeal and eukaryotic diversity of smooth and pustular microbial mat communities in the hypersaline lagoon of Shark Bay. Geobiology 7: 82-96.

203. Valentin L, Feijoo G, Moreira MT, Lema JM (2006) Biodegradation of polycyclic aromatic hydrocarbon in forest and salt marsh soils by white-rot fungi. International Journal of Biodeterioration and Biodegradation 58:15-21.

204. Frey-Klett P, Burlinson P, Deveau A, Barret M, Tarkka M, Sarniguet A (2011) Bacterial-fungal interactions: hyphens between agricultural, clinical, environmental, and food microbiologists. Microbiology and Molecular Biology Review 75: 583-609.

205. Field CB, Behrenfeld MJ, Randerson JT, Falkowski P (1998) Primary production of the biosphere: integrating terrestrial and oceanic components. Science 281:237-240. 
Citation: Olajire AA, Essien JP (2014) Aerobic Degradation of Petroleum Components by Microbial Consortia. J Pet Environ Biotechnol 5: 195. doi:10.4172/2157-7463.1000195

Page 22 of 22

206. Grossart HP, Levold F, Allgaier M, Simon M, Brinkhoff T (2005) Marine diatom species harbour distinct bacterial communities. Environmental Microbiology 7: 860-873.

207. Biegala IC, Kennaway G, Alverca E, Lennon JF, Vaulot D, Simon N (2002) Identification of bacteria associated with dinoflagellates (Dinophyceae) Alexandrium spp. using tyramide signal amplification-fluorescent in situ hybridization and confocal microscopy. Journal of Phycology 38:404-411.

208. Crump BC, Armbrust EV, Baross JA (1999) Phylogenetic analysis of particleattached and free-living bacterial communities in the Columbia river, its estuary, and the adjacent coastal ocean. Applied and Environmental Microbiology 65 3192-3204.

209. Allgaier M, Riebesell U, Vogt M, Thyrhaug R, Grossart HP (2008) Coupling of heterotrophic bacteria to phytoplankton bloom development at different $\mathrm{pCO}_{2}$ levels: a mesocosm study. Biogeosciences 5: 1007-1022.

210. Jasti S, Sieracki ME, Poulton NJ, Giewat MW, Rooney-Varga JN (2005) Phylogenetic diversity and specificity of bacteria closely associated with Alexandrium spp. and other phytoplankton. Applied and Environmental Microbiology 71: 3483-3494.

211. Sapp M, Schwaderer AS, Wiltshire KH, Hoppe HG, Gerdts G, Wichels A (2007) Species-specific bacterial communities in the phycosphere of microalgae? Microbiology and Ecology 53:683-699.

212. Hube AE, Heyduck-Söller B, Fischer U (2009) Phylogenetic classification of heterotrophic bacteria associated with filamentous marine cyanobacteria in culture. Systematic and Applied Microbiology 32: 256-265.

213. Cole JJ (1982) Interactions between bacteria and algae in aquatic ecosystems Annual Review of Ecology, Evolution and Systematics 13: 291-314.

214. Rivas MO, Vargas P, Riquelme CE (2010) Interactions of botryococcus brauni cultures with bacterial biofilms. Microbial Ecology 60: 628-635.

215. Bell WH, Lang JM, Mitchell R (1974) Selective stimulation of marine bacteria by algal extracellular products. Limnology and Oceanography 19: 833-839.

216. Amin SA, Green DH, Hart MC, Küpper FC, Sunda WG, Carrano CJ (2009) Photolysis of iron-siderophore chelates promotes bacterial-algal mutualism. Proceeding of National Academy of Sciences USA, 106: 17071-17076.

217. Hopkinson BM, Roe K, Barbeau KA (2008) Heme uptake by microscilla marina and evidence for heme uptake systems in the genomes of diverse marine bacteria. Applied and Environmental Microbiology 74: 6263-6270.

218. Croft MT, Lawrence AD, Raux-Deery E, Warren MJ, Smith AG (2005) Algae acquire vitamin $B_{12}$ through a symbiotic relationship with bacteria. Nature 438 : 90-93.

219. Mouget JL, Dakhama A, Lavoie MC, Delanoue J (1995) Algal growth enhancement by bacteria - is consumption of photosynthetic oxygen involved. FEMS Microbiology and Ecology 18: 35-43.

220. Huenken M, Harder J, Kirst GO (2008) Epiphytic bacteria on the antarctic ice diatom amphiprora kufferathii manguin cleave hydrogen peroxide produced during algal photosynthesis. Plant Biology 10: 519-526.

221. Villareal TA (1990) Laboratory culture and preliminary characterization of the nitrogen-fixing Rhizosolenia-Richelia symbiosis. Marine Ecology 11:117-132.

222. Kneip C, Lockhart $P$, Voß CMaier U-G (2007) Nitrogen fixation in eukaryotes new models for symbiosis. BMC Evolutionary Biology 7:55.

223. Moisander PH, Beinart RA, Voss M, Zehr JP (2008) Diversity and abundance of diazotrophic microorganisms in the South China sea during intermonsoon. ISME Journal 2: 954-967.

224.Bull AT, Ward AC, Goodfellow M (2000) Search and discovery strategies for biodiscovery: The paradigm shift. Microbiological and Molecular Biology Reviews 64: 573-606.

225. Glöckner FO, Joint I (2010) Marine microbial genomics in Europe: Current status and perspectives. Microbial Biotechnology 3: 576-581.

226. Joint I, Mühling M, Querellou J (2010) Culturing marine bacteria - an essential prerequisite for biodiscovery. Microbial Biotechnology 3: 564-575.

227. Bertrand J-C, Almallah M, Acquaviva M, Mille G (1990) Biodegradation of hydrocarbons by an extremely halophilic archae bacterium. Lett. Appl. Microbiol. 11: 260-263.

228. Ward DM, Brock TD (1978) Hydrocarbon biodegradation in hypersaline environments. Appl. Environ. Microbiol. 35: 353-359.
229. Gauthier MJ, Lafay B, Christen R, Fernandez L, Acquaviva M, Bonin P et al. (1992) Marinobacter hydrocarbonoclasticus gen. nov., sp. nov., a new, extremely halotolerant, hydrocarbon-degrading marine bacterium. Int. J. Syst. Bacteriol. 42: 568-576.

230. Abed RMM, Al-Thukair A, DeBeer D (2006) Bacterial diversity of cyanobacterial mat degrading petroleum compounds at elevated salinities and temperatures. FEMS Microbiol. Ecol. 57: 290-301.

231. Fernandez-Linares L, Acquaviva M, Bertrand J-C, Gauthier M (1996) Effect of sodium chloride concentration on growth and degradation of eicosane by the marine halotolerant bacterium Marinobacter hydrocarbonoclasticus. System Appl. Microbial. 19: 113-121.

232. Kulichevskaya IS, Milekhina EI, Borzenkov IA, Zvyagintseva IS, Belyaev SS (1992) Oxidation of petroleum hydrocarbons by extremely halophilic archae bacteria. Microbiology 60: 596-601.

233. Hinteregger C, Streischsberg F (1997) Halomonas sp., a moderately halophilic strain, for biotreatment of saline phenolic waste-water. Biotechnol. Lett. 19: 1099-1102.

234. Bastos AER, Moon DH, Rossi A, Trevors JT, Tsai SM (2000) Salt-tolerant phenol degrading microorganisms isolated from Amazonian soil samples. Arch. Microbiol. 174: 346-352.

235. Emerson D, Chauchan S, Oriel P, Breznak JA (1994) Haloferax sp. D1227, a halophilic archaeon capable of growth on aromatic compounds. Arch. Microbiol. 161: 445-452.

236. Kleinsteuber S, Müller RH, Babel W (2001) Expression of the 2,4-D degradative pathway of pJP4 in an alkaliphilic, moderately halophilic soda lake isolate, Halomonas sp. EF43. Extremophiles 5: 375-384.

237. Fairley DJ, Wang G, Rensing C, Pepper IL, Larkin MJ (2006) Expression of gentisate 1,2-dioxygenase (gdoA) genes involved in aromatic degradation in two haloarchaeal genera. Appl. Microbiol. Biotechnol. 73: 691-695.

238. Cuadros-Orellana S, Pohlschroder M, Durrant LR (2006) Isolation and characterization of halophilic archaea able to grow in aromatic compounds. Int. Biodeter. Biodegrad. 57: 151-154.

239. Fu W, Oriel P (1999) Degradation of 3-phenylpropionic acid by Haloferax sp. D1227. Extremophiles. 3: 45-53.

240. Li H, Liu YH, Luo N, Zhang XY, Luan TG, Hu, JM, et al (2006) Biodegradation of benzene and its derivatives by a psychrotolerant and moderately haloalkaliphilic Planococcus sp. strain ZD22. Res Microbiol 157: 629-636.

241. Nicholson CA, Fathepure BZ (2006) Isolation and characterization of a halophile that degrades benzene as the sole carbon and energy source, in $106^{\text {th }}$ American Society for Microbiology (Orlando,FL).

242.Dalvi S, Azetsu S, Patrauchan MA, Aktas DF, Fathepure BZ (2012) Proteogenomic elucidation of the initial steps in the benzene degradation pathwayof a novel halophile, Arhodomonas sp. Strain Rozel, isolated from a hypersaline environment. Appl. Environ. Microbiol. 78: 7309-7316.

243. Sei A, Fathepure BZ (2009) Biodegradation of BTEX at high salinity by an enrichment culture from hypersaline sediments of Rozel Point at Great Salt Lake. J. Appl. Microbiol. 107: 2001-2008.

244. Azetsu S, Nicholson C, Najar F, Roe B, Fathepure B (2009) Physiological and genomic analysis of BTEX degradation in novel Arhodomonas strains, isolated from hypersaline environments, in $109^{\text {th }}$ American Society for Microbiology (Philadelphia, PA).

245. Berlendis S, Cayol J-L, Verhe F, Laveau S, Tholozan J-C, Ollivier B, et al. (2010) First evidence of aerobic biodegradation of BTEX compounds by pure cultures of Marinobacter. Appl. Biochem. Biotechnol. 160: 1992-1999.

246. Ashok T, Saxena S, Musarrat J (1995) Isolation and characterization of four polycyclic aromatic hydrocarbon degrading bacteria from soil near an oil refinery. Lett. Appl. Microbiol. 21: 246-248. 